Document downloaded from:

http://hdl.handle.net/10251/60256

This paper must be cited as:

Mulet Salort, JM.; Llopis Torregrosa, V.; Primo Planta, C.; Marques Romero, MC.; Yenush, L. (2013). Endocytic regulation of alkali metal transport proteins in mammals, yeast and plants. Current Genetics. 59(4):207-230. doi:10.1007/s00294-013-0401-2.

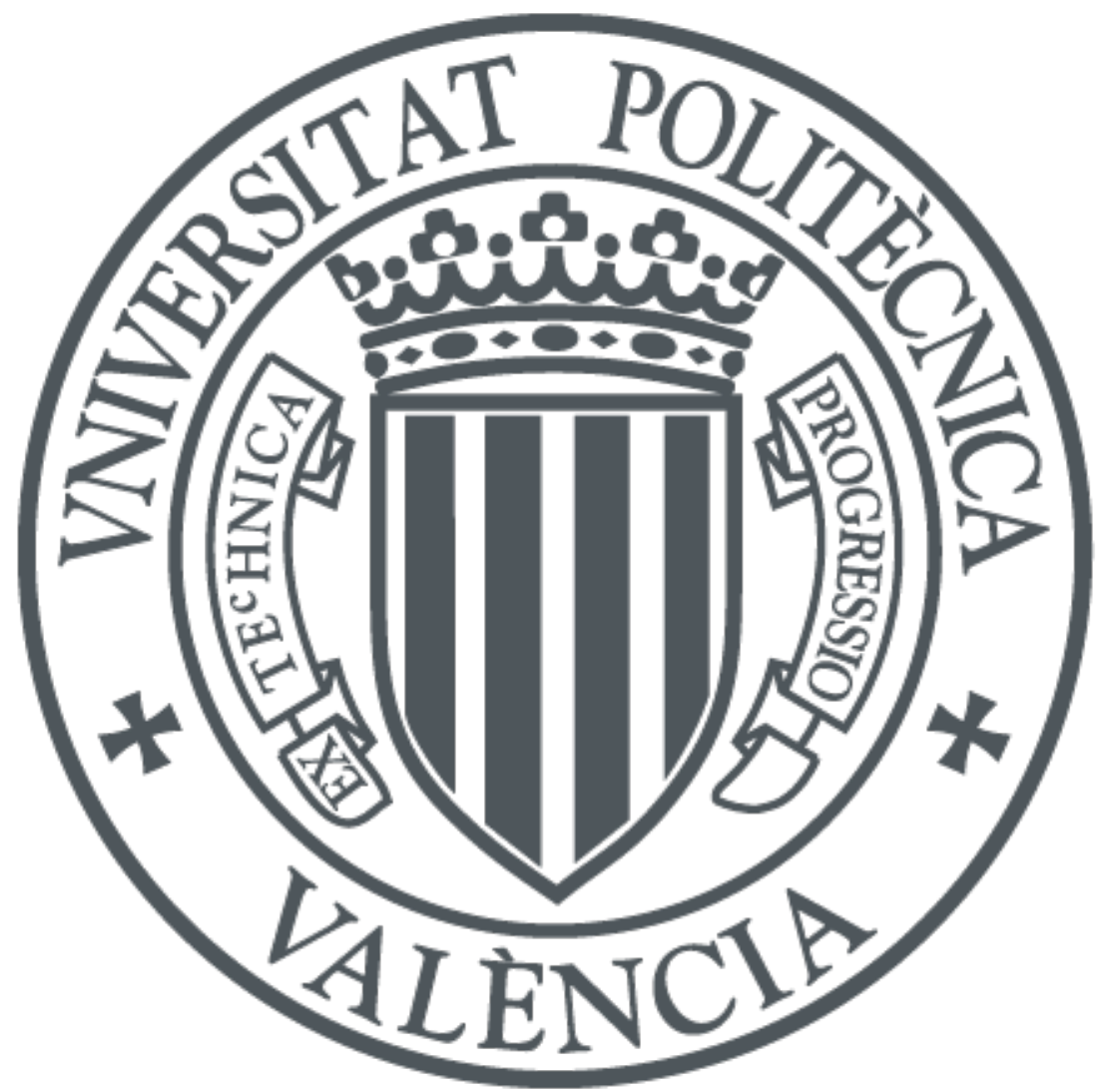

The final publication is available at

http://dx.doi.org/10.1007/s00294-013-0401-2

Copyright Springer Verlag (Germany)

Additional Information 


\section{Endocytic Regulation of Alkali Metal Transport Proteins in Mammals, Yeast and Plants}

José Miguel Mulet, Vicent Llopis-Torregrosa, Cecilia Primo, Mª Carmen Marqués, Lynne Yenush

Instituto de Biología Molecular y Celular de Plantas (IBMCP), Universitat Politècnica de València-

Consejo Superior de Investigaciones Científicas, Avd. de los Naranjos s/n Valencia, Spain 46022

Corresponding Author:

Lynne Yenush

Email: 1ynne@ibmcp.upv.es

Phone: +34963879375

Fax: +3496387 7859

Key Words: Ion homeostasis, endocytic regulation, ubiquitylation, ESCRT

The relative concentrations of ions and solutes inside cells are actively maintained by several classes of transport proteins, in many cases against their concentration gradient. These transport processes, which consume a large portion of cellular energy, must be constantly regulated. Many structurally distinct families of channels, carriers, and pumps have been characterized in considerable detail during the past decades and defects in the function of some of these proteins have been linked to a growing list of human diseases. The dynamic regulation of the transport proteins present at the cell surface is vital for both normal cellular function and for the successful adaptation to changing environments. The composition of proteins present at the cell surface is controlled on both the transcriptional and post-translational level. Post-translational regulation involves highly conserved mechanisms of phosphorylation- and ubiquitylation-dependent signal transduction routes used to modify the cohort of receptors and transport proteins present under any given circumstances. In this review, we will summarize what is currently known about one facet of this regulatory process: the endocytic regulation of alkali metal transport proteins. The physiological relevance, major contributors, parallels and missing pieces of the puzzle in mammals, yeast and plants will be discussed.

\section{IMPORTANCE OF ALKALI METAL TRANSPORTERS}

The regulation of ion homeostasis is critical for cell viability. Monovalent and divalent cations are required for many cellular functions, but in excess, they become toxic. Therefore, cells have developed sophisticated mechanisms to ensure proper uptake, utilization and storage of these molecules, while avoiding toxicity. As ions exist as charged molecules, not easily able to diffuse through the plasma membrane, several types of transport proteins have evolved to control both the influx and efflux of these molecules, in many cases against their concentration gradient. Moreover, the concentration of these ions is not uniform within the cell. Accordingly, each organelle contains specific transport proteins that function to maintain adequate ion concentrations within these compartments. These transport proteins can be classified into three functional categories: channels, carriers and pumps. The coordinated regulation of these proteins maintains the homeostatic concentrations of ions both within cells and in the organs and interstitial fluids of multi-cellular organisms.

The human genome contains at least 232 genes that encode pore-forming subunits of plasma membrane ion channels (Jegla, et al. 2009). The physiological relevance of this class of molecules is highlighted by the considerable number of human diseases classified as "channelopathies". In most cases, these illnesses are caused by mutations in ion transporter proteins present at the plasma membrane, which affect neuronal, muscular or endocrine tissues, and include many types of epilepsy, ataxia, hypertension, migraines, cardiac arrhythmias and some forms of diabetes mellitus (Kullmann 2010, Rolim, et al. 2010, Webster and Berul 2013).

In the model plant Arabidopsis thaliana, there are approximately 880 putative cation transporter proteins, which can be classified into 46 different families (Mäser, et al. 2001). These proteins play an important role in maintaining normal homeostasis, but are also required for effective adaptation to many types of abiotic stresses, like drought or soil salinization. Therefore, understanding the regulation of gene expression and activity of these ion transport proteins is important for crop improvement programs aimed at increasing tolerance to arid soils world-wide. The baker's yeast, Saccharomyces cerevisiae, has served as an excellent model system for both the identification and characterization of many 
ion transport proteins. For example, the first two plant potassium channels were cloned by complementation of a yeast mutant defective in potassium transport (Anderson, et al. 1992, Kullmann 2010, Sentenac, et al. 1992). Moreover, many mammalian transporters have been successfully expressed and functionally characterized in this model organism and it has also been used as a platform for high-throughput $\mathrm{K}^{+}$channel inhibitor screens (Anderson, et al. 1994, Hasenbrink, et al. 2005, Schwarzer, et al. 2008, Tang, et al. 1995, Zaks-Makhina, et al. 2004).

Approximately 320 genes ( 6\% of the yeast genome) have been predicted to encode for proteins directly involved in the transport of small molecules across membranes (Van Belle and André 2001). Nine of these yeast genes are known to encode alkali metal transport proteins localized to the plasma or organellar membranes, many of which have mammalian and plant orthologues (Arino, et al. 2010, Mäser, et al. 2001, Wolfe and Pearce 2006). The function of the transporters encoded by these genes has been extensively characterized, but less is known about how their activity is regulated.

\section{REGULATION OF ALKALI METAL TRANSPORTERS}

As with the majority of proteins, alkali metal transporters are regulated both transcriptionally and post-translationally. Transcriptional regulation ensures the proper tissue-specific and temporal expression of these transporters and is also responsible for long term adaptation to changes in environmental conditions. For example, several hormones and neuropeptides are known to regulate the expression of $\mathrm{K}^{+}$ channels in cardiac tissue (Rosati and McKinnon 2004). Another important facet of alkali transporter regulation, with the potential to respond more quickly to acute changes, is the post-translational regulation of transporter activity. One clear example is the phosphorylation-dependent regulation of the activity of the $\mathrm{Na}^{+} / \mathrm{H}^{+}$antiporter SOS1 (salt overly sensitive 1) in the model plant, Arabidopsis thaliana. Genetic, biochemical and structural data have shown that phosphorylation of the auto-inhibitory C-terminal domain by the SOS2-SOS3 protein kinase complex leads to activation of this alkali metal transporter by causing a conformational change that favors the open conformation (Núñez-Ramírez, et al. 2012, Quintero, et al. 2011).

As mentioned above, transport proteins can be regulated on many levels. As they are integral membrane proteins, which, in many cases, are composed of multiple subunits, their biosynthesis is complex. Upon co-translational insertion into the lipid bilayer of the endoplasmic reticulum (ER), these proteins must be correctly folded, assembled and modified to generate the active form of the transporter. At this juncture, these proteins are subjected to quality control and sorting processes to ensure delivery of properly assembled proteins to the correct cellular membrane. Integral membrane proteins that are not properly folded and/or assembled are retained in the ER and ultimately degraded in the proteosome by the endoplasmic reticulumassociated degradation (ERAD) pathway, which is thought to represent an important step of integral membrane quality control in the secretory pathway. This complex and wellstudied process has been subject of several recent reviews and will not be discussed further here (Brodsky 2012, Hampton and Sommer 2012, Needham and Brodsky 2013, Smith, et al. 2011). Upon exit from the ER, properly folded proteins are subsequently transported to the Golgi where they are sorted either to the plasma membrane or to endosomes which generally arrive to the degradative organelle (lysosomes in mammals or the vacuole in plants and yeast). Resident vacuolar proteins are sorted to endosomes in a ubiquitin-dependent manner. The molecular mechanisms controlling this sorting step are still being characterized. Some plasma membrane proteins, for example, the yeast general amino acid permease, Gap1, also follow this Golgiendosome-vacuole pathway under certain environmental conditions. More specifically, when yeast cells are grown in media containing a preferred nitrogen source, newly synthesized Gap1 does not arrive to the plasma membrane. Instead, it is ubiquitylated and delivered from the Golgi to the vacuole for degradation via endosomes. However, when cells are grown in poor nitrogen sources, Gap1 is delivered to the plasma membrane (Roberg, et al. 1997). Similar vacuolar sorting is observed for the Fur4 uracil permease in the presence of excess substrate (Blondel, et al. 2004).

An additional level of regulation of transport proteins involves the post-translational control of the removal from the plasma membrane. This mode of regulation plays a key role in determining the amount of functional transporter present under any given circumstances and also plays an important role in plasma membrane protein quality control. Many components of the cellular machinery required to carry out this process are highly conserved among eukaryotic organisms. Here we will focus on summarizing what is known about this endocytic regulation of alkali metal transporters and highlight the parallels and gaps in our knowledge in mammals, yeast and plants. 


\section{ENDOCYTOSIS OF TRANSPORT PROTEINS: WHY, WHEN AND HOW?}

The endocytic removal of plasma membrane proteins plays at least two important roles: removal of damaged or misfolded proteins and remodeling of the composition of proteins present in the plasma membrane in response to environmental changes.

The role of endocytosis as a mechanism to remove damaged or misfolded proteins has been most clearly demonstrated in yeast. Studies of temperature-sensitive alleles of both the Ste2 pheromone receptor and the Pmal $\mathrm{H}^{+}$-ATPase have demonstrated rapid endocytosis and vacuolar degradation when protein misfolding is induced by shifting cells to the restrictive temperature (Gong and Chang 2001, Jenness, et al. 1997). In the case of Pmal, this internalization and degradation process was shown to require ubiquitylation (Liu and Chang 2006).

Many examples of plasma membrane protein composition remodeling in response to extracellular stimuli have been described in mammals and yeast. The nature of the stimulus may be receptor ligand binding, excess substrate, nutritional status or stress conditions. Once endocytosed, plasma membrane proteins can be recycled back to the membrane or sorted into endocytic vesicles that mature into multivesicular bodies (MVB, see below), which ultimately fuse with the degradative organelle (lysosome in mammals and vacuole in yeast and plants).

Many classes of plasma membrane proteins are regulated by these internalization and sorting events, but they will not be discussed extensively here. Several recent reviews include a broad discussion of vesicle trafficking and the variety of plasma membrane proteins controlled by these regulatory processes in yeast, plants and mammals (Clague, et al. 2012, MacGurn, et al. 2012, Peer 2011, Tian and Xie 2013). In this review, we will focus mainly on the ubiquitindependent endocytic down-regulation of alkali metal transporters.

\section{Importance of target protein ubiquitylation}

In the majority of cases, this process of endocytosis and eventual degradation in the lysosome/vacuole depends on the specific and timely ubiquitylation of the target proteins (Hicke and Dunn 2003) (see below). In some cases, this post-translational modification is sufficient for endocytosis and subsequent degradation, whereas in other cases, it is required for lysosomal/vacuolar degradation, but not for endocytosis (Hicke and Riezman 1996, Huang, et al. 2007).
Ubiquitin is an evolutionarily-conserved 76 amino acid protein. It serves as a multifunctional post-translational modification for diverse target proteins. The first function of ubiquitin discovered was as a signal for proteosomal degradation of cytosolic proteins (Pickart 2004). The covalent attachment of the ubiquitin peptide to target proteins is referred to as ubiquitin conjugation or ubiquitylation (also ubiquitination). It is the result of the formation of an isopeptide bond between the C-terminal glycine residue of ubiquitin and the $\varepsilon$-amino group of a lysine present in the target protein.

The formation of this bond requires three sequential reactions catalyzed by a ubiquitin activating enzyme referred to as E1, a ubiquitin conjugating enzyme, called E2 and an E3 ubiquitin ligase enzyme.

In general, genomes encode for few E1 activating enzymes. The human genome contains 2 ubiquitin-specific E1 genes (Schulman and Harper 2009). One ubiquitin-specific E1 gene is present in $S$. cerevisiae and 2 are found in Arabidopsis thaliana (Chen and Hellmann 2013, Gao, et al. 2013).

There are many more E2 ubiquitin conjugating enzymes (11 in yeast, and roughly 35 and 40 in humans and Arabidopsis thaliana, respectively) (Chen and Hellmann 2013, Ye and Rape 2009). However, the maximum diversity is found in the E3 ubiquitin ligase enzymes. There are estimated to be more than 50 E3 ubiquitin ligases in $S$. cerevisiae, over 600 in humans and over 1000 in Arabidopsis thaliana (Chen and Hellmann 2013, Gao, et al. 2013, Michelle, et al. 2009).

The explanation for this considerable diversity in the E3 ubiquitin ligase family resides in the fact that these proteins are responsible for target protein interaction and must be able to specifically interact with the myriad of protein substrates which are targeted for ubiquitylation.

E3 ubiquitin ligase enzymes are generally divided into two major families: RING (really interesting new gene) and HECT (homologous to $\underline{E} 6-A P \underline{C}$ terminus) (Metzger, et al. 2012). The RING family contains the vast majority of E3 ubiquitin ligases and is functionally distinct from the HECT family enzymes. RING E3 ligases serve as a scaffold to facilitate the direct transfer of the ubiquitin moiety from the E2 enzyme to the target protein. By contrast, the HECT family members directly participate in the catalytic transfer of ubiquitin to target proteins. These E3 ubiquitin ligases accept ubiquitin on catalytic cysteine residues from their cognate E2 ubiquitin conjugating enzyme and catalyze the subsequent transfer of ubiquitin to the target protein.

Ubiquitylation is a reversible process and the hydrolysis of the ubiquitin-target isopeptide bond is catalyzed by a family of enzymes known as 
deubiquitylating enzymes or DUBs. Earlier estimates stated that the human genome encodes for approximately 80 functional DUBs (Nijman, et al. 2005). More recently, sequence analysis methods predict the presence of $\sim 125$ human DUBs, whereas there are approximately 25 in $S$. cerevisiae and approximately 50 have been predicted in Arabidopsis thaliana (Gao, et al. 2013). However, it remains to be established whether all of these genes are functionally expressed and whether they are specific for ubiquitin or ubiquitin-like molecules (i.e. SUMO).

Proteins can either be mono-ubiquitylated on one or more lysine residues or poly-ubiquitylated by chains of ubiquitin. The ubiquitin protein contains 7 lysine residues which, along with the N-terminus, are also targets for ubiquitin conjugation. The successive addition of ubiquitin moieties leads to the formation of poly-ubiquitin chains with different structures and functions (Komander and Rape 2012). These ubiquitin chains are known to have varying affinities for the different ubiquitin-binding domains (UBD). Proteins containing these UBDs are responsible for decoding the information contained within the "ubiquitin code" and therefore determine the functional outcome of these post-translational modifications (Husnjak and Dikic 2012).

All possible ubiquitin linkages have been observed in cells (Kulathu and Komander 2012). However, the two most abundant types of polyubiquitin chains have been most extensively studied: those linked through lysine 48 (K48) and those formed by linking additional ubiquitin moieties to lysine 63 (K63). In general, K48 poly-ubiquitylation directs target proteins for degradation by the proteosome, while K63 polyubiquitylation can have several functions in cell signaling, one of which is to direct the endocytosis and/or lysosomal/vacuolar degradation of target proteins (Komander and Rape 2012). Endocytosis and degradation of plasma membrane proteins can also be initiated by single or multi-site mono- ubiquitylation of target proteins. In the case of alkali metal transporters, in mammalian cells, this ubiquitylation step is frequently carried out by the HECT family E3 ubiquitin ligase, Nedd4-2.

\section{ENDOCYTIC REGULATION OF ION TRANSPORTERS \\ Mammals}

The HECT family of mammalian E3 ubiquitin ligases contains 28 members that can be divided into three groups based on the $\mathrm{N}$-terminal domain architecture: the Nedd4 (neural precursor cell-expressed developmentally downregulated gene 4) family, the HERC family (which contain a HECT domain and one or more regulator of chromosome condensation 1 (RCC1)-like domains (RLDs)) and a third family referred to as "other HECTs" (Rotin and Kumar 2009). The HERC and other HECT families contain 6 and 13 members, respectively, and have apparently diverse cellular functions which are still being defined. Notably, several of the genes encoding these enzymes have been associated with cancer, such as E6AP, EDD and HACE1 via different mechanisms (Clancy, et al. 2003, Scheffner, et al. 1993, Zhang, et al. 2007).

The Nedd4 family is comprised of 13 members sharing a common domain structure (Rotin and Kumar 2009). At the N-terminus, these proteins contain a C2 domain. This 120 amino acid domain binds phospholipids in a $\mathrm{Ca}^{+2}$-dependent manner and is therefore responsible for the association with membranes.

The central region contains 2-4 repeats of a WW protein-protein interaction domain. WW domains are 38-40 amino acids long, formed by a 3stranded $\beta$ sheet and named for the two invariable Trp residues, separated by $20-22$ amino acids. In many cases, these domains bind proline-rich sequences with a minimum consensus recognition sequence: L/PPxY (PY motif). WW domains have also been reported to bind phosphoserine or phosphothreonine residues (Lu, et al. 1999). Therefore, they have the potential to mediate a variety of protein-protein interactions (Jolliffe, et al. 2000).

The HECT E3 catalytic domain is located at the $\mathrm{C}$-terminus. These domains are approximately 350 amino acids in length and contain a conserved, catalytic Cys residue which accepts the ubiquitin molecule from the cognate E2 conjugating enzyme, forming a transient thioester bond, and then transfers it to the substrate molecule (Huibregtse, et al. 1995).

Nedd4 (also called Nedd4-1) and Nedd4-2 (also called Nedd4L) are closely related genes that are well-conserved in eukaryotes. Phylogenetic studies suggest that Nedd4 was the ancestral form and that Nedd4-2 is likely the result of gene duplication (Yang and Kumar 2010). Nedd4 was first identified in a screen for genes highly expressed in early stages of development in the central nervous system of mouse embryos (Kumar, et al. 1992). Nedd4 was subsequently found to be widely expressed, whereas Nedd4-2 is expressed mainly in lung, heart, kidney, brain, and liver (Kumar, et al. 1997, Yang and Kumar 2010).

Despite their sequence similarity, Nedd4 and Nedd4-2 have different physiological functions, as shown by a systematic analysis of their substrates and the different phenotypes presented by mouse knock-out models (Boase, et al. 2011, Cao, et al. 2008, Persaud, et al. 2009, Shi, et al. 2008). The function of Nedd4 is related to the 
control of cell growth, as nedd $4^{-/}$knock-out mice display growth retardation (with a $60 \%$ reduction in body weight compared to wild type littermates) and associated perinatal lethality (Cao, et al. 2008). This defect is thought to be due to the down-regulation of the Insulin-like Growth Factor (IGF)-1 receptor, likely via modulation of the Grb10 adaptor protein (Cao, et al. 2008). However, the detailed molecular mechanism is still being defined. This knock-out mouse model and various biochemical studies also provide evidence that Nedd4 regulates, directly or indirectly, $\mathrm{T}$ cell function, neuromuscular junctions, VEGF receptor 2 function and possibly the PTEN protein phosphatase, although this last case is still controversial (Christie, et al. 2012, Liu, et al. 2009, Morrione, et al. 1999, Murdaca, et al. 2004, Peruzzi, et al. 2001, Vecchione, et al. 2003, Wang, et al. 2007, Yang, et al. 2008, Yang and Kumar 2010).

Interestingly, the first substrate identified for Nedd4 was the epithelial $\mathrm{Na}^{+}$channel, ENaC, (Staub, et al. 1996). ENaC is a heterotrimeric channel composed of PY-containing $\alpha, \beta$ and $\gamma$ subunits. These WW domain-binding sequences are mutated in patients suffering from inherited forms of hypertension known as Liddle's syndrome. These mutations lead to the overaccumulation of the ENaC channel, which causes increased $\mathrm{Na}^{+}$reabsorption by the kidneys and leads to hypertension (Shimkets, et al. 1994).

Further studies and the generation of nedd4-2 $2^{-1}$ mouse models have established that it is Nedd42, and not Nedd4, which plays an important physiological role in down-regulating $\mathrm{ENaC}$ by catalyzing its ubiquitylation, which leads to its degradation in the lysosome (Figure 1) (Boase, et al. 2011, Shi, et al. 2008, Snyder, et al. 2004). The first mouse model generated by Shi and colleagues suggested that Nedd4-2 function was not necessary for proper development. Nedd4-2 loss-of-function mice presented higher blood pressure, which was exacerbated on a high-salt diet, leading to cardiac hypertrophy and decreased long-term cardiac function. These phenotypes were attributable to increased $\mathrm{ENaC}$ activity based on biochemical analysis of $\mathrm{ENaC}$ protein levels and phenotypic improvement upon treatment with the ENaC-specific inhibitor, amiloride. More recently, a second knock-out mouse was constructed in an inbred genetic background (Boase, et al. 2011). In this case, the phenotypes were more severe, leading to perinatal death of the pups caused by failure to inflate the lungs due to increased ENaC activity in this tissue. These two studies confirm the key physiological role of Nedd4-2 in ENaC regulation.
Numerous studies suggest that the role of Nedd42 in regulating alkali cation homeostasis involves many more transporters expressed in various tissues, including voltage-gated sodium channels and several potassium transporters (Table 1). In these cases, Nedd4-2 is also proposed to function by controlling the ubiquitin-dependent endocytosis and subsequent degradation of these transporters in the lysosome. Therefore, Nedd4-2 plays an important role in the maintenance of ion homeostasis by determining the levels of plasma membrane accumulation of many transport proteins expressed in various tissues. In fact, in a very recent study, the analysis of a tissue specific Nedd4-2 knock-out (renal tubular) uncovered a role for Nedd4-2 in the regulation of both $\mathrm{ENaC}$ and the $\underline{\mathrm{Na}}^{+} \mathrm{Cl}^{-}$co-transporter, $\mathrm{NCC}$, confirming earlier biochemical studies (Arroyo, et al. 2011, Ronzaud, et al. 2013). Therefore, the role of Nedd4-2 in both kidney and lung are well established by these studies. The physiological consequences of Nedd4-2-dependent regulation of other transporters may require the generation of more tissue-specific Nedd4-2 loss-of-function models. In any case, these studies, taken together, demonstrate the importance of Nedd42-mediated ubiquitylation-dependent regulatory processes in the maintenance of ion homeostasis in mammals.

\section{Yeast}

The yeast genome encodes one Nedd4 family orthologue called Rsp5 (Gajewska, et al. 2003, Huibregtse, et al. 1995). This essential HECT family E3 ubiquitin ligase has been implicated in many cellular functions, such as transcriptional regulation (proposed target: Rpb1), mRNA export (proposed target: Hpr1), chromatin condensation (together with Apc5, target unknown), and unsaturated fatty acid synthesis (proposed targets: Spt23 and Mga2) (Arnason, et al. 2005, Beaudenon, et al. 1999, Gwizdek, et al. 2005, Harkness, et al. 2002, Hoppe, et al. 2000, Rodriguez, et al. 2003, Shcherbik, et al. 2004, Shcherbik, et al. 2003). Rsp5 is also known to be involved in mitochondrial inheritance and mitochondrial- cytoplasmic protein distribution; although in these cases, the mechanisms are not well-defined (Fisk and Yaffe 1999, Zoladek, et al. 1997). Another important function that has been attributed to Rsp5, similar to its mammalian counterpart Nedd4-2, is the ubiquitylation of a large number of plasma membrane proteins (Belgareh-Touzé, et al. 2008). Here, we will focus on this function of Rsp5.

The yeast model system provided the first evidence of a connection between plasma membrane protein ubiquitylation and endocytosis almost 20 years ago. In this initial study, ubiquitylated forms of the $\mathrm{ABC}$ pheromone 
transporter, Ste6, were shown to accumulate at the plasma membrane in yeast mutants defective in endocytosis (Kölling and Hollenberg 1994). Moreover, mutations in Ste6 that reduced ubiquitylation also prevented down-regulation by impeding the delivery of this transporter to the vacuole, thus showing that ubiquitylation was necessary for both endocytosis and subsequent transporter degradation in this case. Subsequent studies showed that ligand-induced degradation of the Ste 2 pheromone receptor also followed a similar ubiquitin-dependent internalization mechanism and identified Rsp5 as the E3 ubiquitin ligase responsible for the ubiquitylation of the general amino acid permease, Gap1 and the uracil permease Fur4 (Galan, et al. 1996, Hein, et al. 1995, Hicke and Riezman 1996).

Since then, many more transporters have been shown to be down-regulated by ubiquitindependent endocytosis in response to excess ligand, nutritional changes and stress conditions. In almost all cases, Rsp5 is the E3 ubiquitin ligase responsible for this regulation (Lauwers, et al. 2010, Rotin, et al. 2000). Therefore, it is clear that in yeast, as in mammals, this HECT family E3 ubiquitin ligase is a key regulator of plasma membrane protein composition.

The list of transporters that are regulated by Rsp5 contains several metal ion transporters, such as Smf1 (manganese), Zrt1 (zinc) and Ctr1 (copper) (Gitan and Eide 2000, Gitan, et al. 1998, Liu, et al. 2007, Nikko and Pelham 2009, Nikko, et al. 2008, Sullivan, et al. 2007). The Pma1 $\mathrm{H}^{+}$ATPase is also known to be regulated by Rsp5dependent ubiquitylation, but in this case, as part of the Golgi-based quality control mechanism of a misfolded isoform (Pizzirusso and Chang 2004).

As discussed above, the Nedd4-2 HECT E3 ligase is involved in the down-regulation of many alkali metal transport proteins. In yeast, this function of Rsp5 has not been fully addressed, but some data indicate that this E3 ubiquitin ligase may also play a role in alkali metal transporter regulation. For example, we have observed alterations in the growth rate of conditional rsp5 mutants in potassium-limiting media (Figure 2) (Abe and Iida 2003). These growth tests are used to monitor alterations in the accumulation and/or activity of the Trk1 potassium transporter (Navarrete, et al. 2010). Although more experiments are required to fully characterize these phenotypes, they suggest a role for Rsp5 in the regulation of monovalent cation homeostasis.

Additional data suggest that the high affinity potassium transporter, Trk1, undergoes endocytic regulation. Specifically, it was shown that in mutant strains lacking two related protein kinases, Sat4/Hal4 and Hal5, Trk1 is rapidly targeted to the vacuole in the absence of potassium supplementation. Moreover, deletion of the last 35 amino acids of Trk1results in its plasma membrane stability in the hal4 hal5 mutant under all conditions tested (Perez-Valle, et al. 2007).

Yeast two hybrid screens using the C-terminus of Trk1 have failed to identify binding proteins potentially involved in this regulation and no Hal4-dependent phosphorylation of this region has been detected in vitro. However, we have generated preliminary data suggesting that Trk1 is ubiquitylated (J. Peréz-Valle, V. Llopis, L. Yenush, unpublished data).

Interestingly, in the case of the hal4 hal5 mutant, Trk1 is not the only transport protein that aberrantly accumulates in the vacuole in the absence of potassium supplementation. Amino acid permeases, such as Gap1 (general amino acid permease), Tat2 (tryptophan), Can1 (arginine), and Mup1 (methionine), the Fur4 uracil permease and the Hxt1 glucose permease have also been shown to be degraded in the vacuole in the hal4 hal5 mutant, leading to alterations in carbon and nitrogen uptake and metabolism (Perez-Valle, et al. 2007, PerezValle, et al. 2010). The detailed mechanism of Hal4 and Hal5 function is currently under investigation.

\section{Plants}

As mentioned above, plant genomes contain more than 1000 E3 ubiquitin ligase genes, but in Arabidopsis thaliana, for example, there is only a small family of 7 HECT-containing E3 ubiquitin ligases (Downes, et al. 2003, Gao, et al. 2013). Moreover, none of these family members share the same C2-WWs-HECT domain architecture as the Nedd4 family.

The N-terminal architecture of the 7 HECT family E3 ligases in Arabidopsis thaliana, called ubiquitin protein ligase (UPL) $1-7$, is quite varied. UPL1 and 2 are large proteins $(>3500$ amino acids), which contain ubiquitin associated (UBA) and ubiquitin interacting motif (UIM) domains in their N-terminal sequences. UPL3 and 4 are smaller $(<2000$ amino acids) and are characterized by the presence of 4 armadillo repeats in their N-terminus. UPL5, the smallest family member (873 amino acids), contains three repeats of ubiquitin-like sequence and a C-type lectin binding domain. The last members, UPL6 and 7, composed of approximately 1000 amino acids, each contain two predicted membranespanning domains and a calmodulin-binding IQ motif (Downes, et al. 2003).

The functions of the 7 HECT E3 ubiquitin ligases in Arabidopsis thaliana have only been partially characterized. No data are available for the functions of UPL1, 2, 4, 6 or 7. Analysis of 
UPL3 loss-of-function mutants initially implicated this enzyme in trichome development (Downes, et al. 2003). More recently, it was reported that UPL3 regulates the transcription factors, GLABROUS 3 (GL3) and ENHANCER OF GL3 (EGL3) (Patra, et al. 2013). These transcription factors are known regulators of trichome development and flavonoid biosynthesis in Arabidopsis thaliana, thus providing a plausible molecular mechanism explaining the upl3 phenotypes.

The ubiquitin ligase activity has only been confirmed for UPL5 (Miao and Zentgraf 2010, Takahashi, et al. 2009). At least one function of this enzyme is related to the regulation of the WRKY53 transcription factor, which controls leaf senescence (Miao and Zentgraf 2010). Accordingly, in this study, they demonstrate in vitro ubiquitylation and physical interaction between UPL5 and WRKY53 and genetic data consistent with UPL5 acting as a negative regulator of WRKY53.

No evidence has emerged indicating that members of Arabidopsis HECT family of E3 ubiquitin ligases are involved in the ubiquitylation of plasma membrane transport proteins. However, it is clear that plant cells also employ mechanisms of endocytic regulation (Geldner 2004, Peer 2011).

Several examples demonstrating the physiological importance of endocytic regulation have been described in plants. For example, the auxin receptor, PIN1, has been shown to undergo ubiquitin-dependent asymmetrical sorting to create the auxin gradient and the iron transporter, IRT1, was recently shown to undergo monoubiquitylation-dependent vacuolar degradation (Barberon, et al. 2011, Löfke, et al. 2013). Moreover, translational fusion of ubiquitin to the plasma membrane $\mathrm{H}^{+}$-ATPase was shown to be sufficient for vacuolar degradation (Herberth, et al. 2012).

Here, we will discuss in more detail three other relevant examples of transporter down-regulation in plants: the KAT1alkali metal transporter, the BOR1 boron transporter and the patternrecognition receptor, flagellin-sensing 2 (FLS2).

KAT1 is a Skaker-like inward rectifying $\mathrm{K}^{+}$ channel whose activity must be properly regulated during stomatal opening and closing (Schachtman, et al. 1992). Specifically, in order for guard cells to close, inward $\mathrm{K}^{+}$currents must decrease to help reduce the turgor pressure.

The phytohormone, abscisic acid, is known to stimulate stomatal closure through various signaling mechanisms, including the activation of anion transport and the down-regulation of $\mathrm{K}^{+}$ uptake (Kim, et al. 2010). One aspect of this regulation involves the stimulated endocytosis of the KAT1 alkali metal transporter (Sutter, et al.
2007). The selective endocytosis of KAT1 contributes to stomatal closure by decreasing the inward $\mathrm{K}^{+}$current. Several studies have suggested that KAT1 is endocytosed and stored in internal vesicles in response to abscisic acid and turgor pressure (Eisenach, et al. 2012, Hurst, et al. 2004, Meckel, et al. 2004, Sutter, et al. 2007). KAT1 does not appear to be degraded under these circumstances. Instead, these vesicles are slowly recycled back to the plasma membrane in a process that requires the SNARE protein, SYP121 (Eisenach, et al. 2012). It is not known whether ubiquitylation is required for the selective, ABA-stimulated endocytic regulation of KAT1.

In plants, a well-studied example of ubiquitindependent endocytic regulation in response to excess substrate is the boron transporter, BOR1 (Figure 1). It has been shown that in response to high boron concentrations, BOR1 is ubiquitylated, endocytosed from the plasma membrane, sorted to the trans-Golgi network/early endosomes (TGN/EE), then to intralumenal vesicles of the multivesicular body (MVB)/late endosome compartment, and finally to the vacuolar lumen for degradation (see below) (Kasai, et al. 2011, Takano, et al. 2005, Viotti, et al. 2010). A target lysine residue has been identified, but the E3 ubiquitin ligase responsible for BOR1 regulation is not yet known (Kasai, et al. 2011). These studies are important as they establish the existence of similar mechanisms of ubiquitin-dependent endocytic regulation in plants, mammals and yeast.

Interestingly, the ubiquitylation of the BOR1 transporter is not necessary for endocytosis, but is required for sorting into the MVBs, similar to what has been observed for the mammalian epidermal growth factor receptor (EGFR) (Huang, et al. 2007, Huang, et al. 2006). The endocytosis of BOR1 requires at least two tyrosine residues present in $\mathrm{Yxx} \Phi$ motifs (where $\mathrm{x}$ is any amino acid and $\Phi$ is a bulky hydrophobic amino acid), which, in mammals, have been shown to bind to a medium $(\mu)$ subunit of adaptor protein (AP) complexes which mediate sorting into clathrin-coated vesicles and different post-Golgi transport pathways (Bonifacino and Traub 2003, Takano, et al. 2010). Thus, BOR1 is thought to be constitutively endocytosed, via the tyrosinebased signals, and recycled back to the plasma membrane under normal conditions. Ubiquitylation of BOR1, leading to its sorting and vacuolar degradation only takes place in the presence of high boron concentrations, thus providing a mechanism of down-regulation to avoid toxicity. Identification of the E3 ubiquitin ligase and the signal transduction pathway 
responding to high boron will be required to fully define this mechanism of endocytic regulation.

One case where the plant E3 ubiquitin ligase responsible for endocytic down-regulation has been identified is for the FLS2 pattern recognition receptor. FLS2 is a plasma membrane-localized leucine-rich repeat receptor-like kinase (LRR-RLK) (GómezGómez and Boller 2000). This receptor binds to bacterial flagellin and is an important component of innate plant immunity (O'Neill 2011). Upon flagellin binding, FLS2 associates with another receptor-like kinase, called BAK1 and the BIK1 cytosolic kinase (Chinchilla, et al. 2007, Heese, et al. 2007, Lu, et al. 2010, Zhang, et al. 2010).

Initial studies showed that upon ligand binding, FLS2 is endocytosed and subsequently degraded (Robatzek, et al. 2006). Using the FLS2interacting BIK1 kinase as a bait protein in a yeast two-hybrid screen, the E3 ubiquitin ligase PUB13 was identified (Lu, et al. 2011). PUB13 and the closely related PUB12 are RING family E3 ubiquitin ligases belonging to the plant $\underline{U}$-box (PUB) family. The E3 ubiquitin ligases contain a U-box N-terminal domain (UND), a U-box domain, and a C-terminal armadillo domain. PUB12 and PUB13 E3 ubiquitin ligases specifically ubiquitylate FLS2 upon ligand binding and thus participate in receptor downregulation. Whether FLS2 ubiquitylation leads to its degradation in the proteosome or in the vacuole was not fully addressed in this study, although it was reported that the proteosome inhibitor, MG132, partially inhibited FLS2 degradation. Importantly, FLS2 represents the first case of ligand-induced ubiquitylationdependent endocytic regulation reported in plants. Whether PUB family E3 ubiquitin ligases are involved in the endocytic regulation of other plasma membrane transporters remains to be determined.

\section{CONTROLLING WHICH TRANSPORT} PROTEINS ARE TARGETED AND WHEN

As discussed previously, ubiquitylationdependent endocytosis is a highly-regulated process. The cell must control which transporters are targeted for degradation and when. This control can be carried out on many levels, such as the modification of transcriptional levels of the genes encoding the transport proteins themselves or the ubiquitin conjugation machinery. Another possibility is the posttranslational modification of the transporters themselves, the E3 ubiquitin ligases or other regulatory components.

Examples of phosphorylation-dependent regulation of transporter proteins have been reported. For example, in yeast, phosphorylation of three serines in the C-terminus of the Ste2, G- protein coupled pheromone receptor facilitates ubiquitylation and thus internalization (Hicke, et al. 1998). Similar examples have been reported in mammals as well (Naik, et al. 1997, PalsRylaarsdam and Hosey 1997). In most cases, the mechanism by which transporter phosphorylation influences its endocytic regulation is not fully understood, but in some cases it is thought to affect the binding of E3 ubiquitin ligase adaptor proteins (see below) (Hatakeyama, et al. 2010, Lee, et al. 2000, Nikko, et al. 2008).

\section{Regulation of E3 Ubiquitin ligases}

As mentioned, the Nedd4-2 E3 ubiquitin ligase binds to PY motifs present in alkali metal transport proteins. This binding has been shown to be regulated by the phosphorylation of Nedd42. Several kinases have been reported to regulate Nedd4 E3 ubiquitin ligases (Rotin and Kumar 2009), but here we will focus on two examples: the regulation of Nedd4-2 by the AMP-activated kinase (AMPK) and by the serum- and glucocorticoid-regulated kinase (Sgk1) (Figure 1). AMPK-dependent phosphorylation of Nedd42 was shown to facilitate its interaction with $\mathrm{ENaC}$, thus leading to channel down-regulation (Bhalla, et al. 2006). In this case, the molecular mechanism involved is still being defined.

In the case of Sgk1, phosphorylation of Nedd4-2 creates binding sites for 14-3-3 proteins and thus blocks the interaction of the E3 ubiquitin ligase with ENaC (Bhalla, et al. 2006, Debonneville, et al. 2001, Ichimura, et al. 2005, Snyder, et al. 2002). The end result is accumulation of $\mathrm{ENaC}$ at the plasma membrane upon Sgk1 activation. The physiological relevance of this regulatory mechanism was recently confirmed by generating a mouse model containing an inducible, renal tubular-specific knock-out of Sgk1 (Faresse, et al. 2012). In this study, they observed a reduction in the amount of $\mathrm{ENaC}$, as expected, but also an important reduction in the amount of the $\mathrm{Na}^{+} / \mathrm{Cl}^{-}$co-transporter, NCC, which together lead to a salt-losing phenotype. The marked reduction in Nedd4-2 phosphorylation also documented in this study demonstrates that Sgk1 is a physiologicallyrelevant Nedd4-2 regulator.

In yeast, the regulation of Rsp5 appears to involve several mechanisms. Very recently, Rsp5 was reported to be phosphorylated, although the kinase involved and the mechanism by which Rsp5 function is affected is unknown (Sasaki and Takagi 2013). However, using yeast two hybrid analyses, we have found no evidence that 14-3-3 proteins bind to the WW domains of Rsp5, as occurs in the case of Nedd4.2 (V. Llopis, L. Yenush, unpublished data). Thus, more studies will be required to clarify if this mode of 
phosphorylation-dependent regulation is as important for Rsp5 as it is for Nedd4-2.

As discussed earlier, many of the alkali metal transporters regulated by Nedd4-2 contain PY motifs capable of interacting with the WW domains of this E3 ubiquitin ligase. However, in yeast, the majority of transport proteins regulated by Rsp5 do not contain PY motifs. At least 18 proteins have been proposed to act as adaptors between Rsp5 and target proteins (Lauwers, et al. 2010). These proteins contain PY motifs that bind to the WW domains of Rsp5 and other domains responsible for target protein recognition. These adaptor proteins have been shown to recruit Rsp5 to substrate proteins in different subcellular locations. For example, a member of the arrestin-related trafficking (ART) family of Rsp 5 adaptors, Ecm21 (also called Art2) was shown to bind to and participate in $\mathrm{Cd}^{+2}$-mediated endocytic regulation of the Smf 1 $\mathrm{Mn}^{+2}$ transporter at the plasma membrane, while adaptor proteins such as Bsd2, Tre1 and Tre2 are necessary for direct vacuolar sorting of the this transporter in the presence of excess substrate (Nikko, et al. 2008, Sullivan, et al. 2007) (Figure 1). Interestingly, there are at least two Bsd2 homologues in mammals, NDFIP1 and NDFIP2 (also known as N4WBP5 and N4WBP5A, respectively). These proteins have been suggested to act as adaptors for Nedd4 family E3 ubiquitin ligases (Shearwin-Whyatt, et al. 2006). In fact, ndfip $1^{-/}$mice exhibit phenotypes similar to mice lacking the gene encoding Itch, which is a Nedd4-family E3 ubiquitin ligase (Oliver, et al. 2006).

Several recent reports have begun to define mechanisms of post-translational regulation of these Rsp5 adaptor proteins in yeast. For example, the founding member of the ART family, Art1 (Lbd19) was shown to be phosphoinhibited by the TORC1-responsive Npr1 kinase (MacGurn, et al. 2011). Phosphorylation of Art1 on multiple sites diminishes the association of Art1 with the plasma membrane, thus decreasing Rsp5-dependent ubiquitylation of target proteins, such as the Can1 arginine permease. Similarly, the Npr1 kinase was shown to phosphorylate the Bul1 and Bul2 Rsp5 adaptor proteins. This phosphorylation also inhibits these adaptor proteins, but in this case, by creating binding sites for 14-3-3 proteins. The association of Bul1 and Bul2 with 14-3-3 proteins prevents the targeting of Rsp5 to Gap1 (Merhi and André 2012). Another ART family member, Rod1 (also known as Art4) has also been shown to be inhibited by 14-3-3 binding, but in this case, the phosphorylation is carried out by the Snf1 kinase and the targeted transporter is the Jen1 lactate permease (Becuwe, et al. 2012). Thus, yeast contains an elaborate system of Rsp5 adaptor proteins that respond to signal transduction pathways to mediate the specific and regulated interaction of the E3 ubiquitin ligase with literally hundreds of possible target proteins.

Interestingly, the ART family of Rsp5 adaptors contains arrestin-like domains in their $\mathrm{N}$ terminus, in addition to the PY motifs (Lin, et al. 2008). A class of mammalian proteins, called $\beta$ arrestins, have been known for many years to mediate the endocytic regulation of a variety of mammalian receptor classes (Lefkowitz, et al. 2006). The ART family from yeast shares similarity with the related $\alpha$-arrestin family in mammals. There are $6 \alpha$-arrestins in the human genome and, similar to the ART family, they contain WW domain-binding PY motifs (Patwari and Lee 2012). At least two studies show that members of the mammalian $\alpha$-arrestin family can recruit Nedd4 ubiquitin ligases to activated receptors (Nabhan, et al. 2010, Shea, et al. 2012). Interestingly, the study by Shea and colleagues also showed that $\alpha$-arrestins can bind $\beta$-arrestins, thus suggesting that these proteins may act in a coordinated manner to regulate the composition of plasma membrane proteins present at the cell surface. Finally, a very recent study suggests that one member of the $\alpha$-arrestin family, thioredoxin-interacting protein (TXNIP), binds to the GLUT1 glucose transporter and is regulated by the Snf1 orthologue, AMPK (Wu, et al. 2013). This data is in good agreement with previous studies showing that TXNIP is a potent inhibitor of glucose uptake (Parikh, et al. 2007, Patwari, et al. 2009). However, these studies show that the C-terminal PY motifs are not required for the inhibition of glucose uptake. Therefore, it remains to be seen whether Nedd4 family members are implicated in this regulatory mechanism.

\section{THE FATE OF UBIQUITYLATED PROTEINS}

As discussed above, cells internalize plasma membrane proteins into vesicles as a regulatory mechanism. Once endocytosed (in the so-called early endosome), these proteins can have different fates. Endocytosed proteins can be constitutively recycled back to the plasma membrane or can be destined for degradation in the lysosome (or vacuole in plants and yeast). In animal cells, receptors that are selected for recycling back to the plasma membrane are sorted away into tubular regions of the early endosome and returned to the plasma membrane (Woodman 2009). In addition to the plasma membrane contribution, early endosomes can also be derived from the TGN (Waguri, et al. 2003).

The early endosome also contains proteins targeted for lysosomal/vacuolar degradation. As 
discussed above, the signal for this degradation can be a mono-ubiquitylation, multiple-site mono-ubiquitylation or K-63 linked polyubiquitin chains (Komander and Rape 2012). This ubiquitylation step is thought to be required for the sorting of target or "cargo" proteins that are to be degraded and, as described in the examples above, may or may not be required for the endocytosis step. Here, we will briefly discuss the components involved and the vesicular route followed by plasma membrane proteins targeted for degradation.

Early endosomes mature into multivesicular bodies (MVB) (also called late endosomes, multivesicular endosomes or pre-vacuolar compartments). The most evident morphological change during this maturation process is the formation of intraluminal vesicles. During MVB formation, proteins that are destined for degradation are selectively retained in this compartment. The molecular mechanisms of this maturation process are still being defined, but it is thought to require several proteins, including components of the endosomal sorting complex required for transport (ESCRT) (see below), COP-I, annexin A2, and the SAND-1/Mon1 protein (Aniento, et al. 1996, Futter and White 2007, Gabriely, et al. 2007, Mayran, et al. 2003, Poteryaev, et al. 2010).

\section{The ESCRT machinery}

\section{Mammals and Yeast}

ESCRT is a protein complex involved in the sorting of ubiquitylated membrane proteins into the intralumenal vesicles of MVBs. In addition, the ESCRT proteins are involved in other cellular processes such as cytokinesis, tumor suppression, and viral budding (see below). The ESCRT machinery was first identified in yeast as class-E vacuolar protein sorting (Vps) mutants (Raymond, et al. 1992). This class of mutants accumulates an exaggerated multi-lamellar prevacuolar endosome-like compartment that does not fuse with the vacuole (Coonrod and Stevens 2010). The ESCRT complex is phylogenetically conserved in eukaryotic cells and is thought to have been present in the last common ancestor of all eukaryotes (Field, et al. 2007). ESCRT-like components can even be found in some archae (Obita, et al. 2007, Samson, et al. 2008). Table 2 contains a summary of the nomenclature for the ESCRT components in yeast, mammals and plants.

In yeast and mammals, ESCRT function starts with cargo recognition by the ESCRT-0 complex. This complex is a heterodimer formed by $\mathrm{Vps} 27 / \mathrm{Hrs}$ and Hse1/STAM1/2, which has been proposed to recognize mono-ubiquitylated cargo through single UIM domains present in both proteins (Katzmann, et al. 2003, Prag, et al.
2007). In addition, Vps27/Hrs interacts with phosphatidylinositol-3-phosphate (PtdIns3P) via its FYVE domain.

ESCRT-I and ESCRT-II complexes are present in the assembled form in the cytoplasm. ESCRTI is a heterotetramer consisting of Vps23/TSG101, Vps28, Vps37 and Mvb12 (Katzmann, et al. 2001). ESCRT-I is recruited to the endosomal membrane via the interaction between Vps23/TSG101 and Vps27/Hrs. The ubiquitin-binding UEV (Übiquitin E2 variant) domain of Vps23/TSG101 is thought to be responsible for cargo sorting. ESCRT-II is a heterotetramer composed of Vps36/EAP45, Vps22/EAP30, and two Vps25/EAP20 molecules (Babst, et al. 2002b). Vps36/EAP45 interacts with PtdIns3P, the ubiquitylated cargo and with the ESCRT-I component, Vps28, via its GLUE domain.

In contrast to ESCRT-I and -II, ESCRT-III assembles in situ with an irregular stoichiometry (Babst, et al. 2002a, Teis, et al. 2008). ESCRTIII assembly is initiated when Vps20/CHMP6 interacts with the ESCRT-II component, Vps25/EAP20 and acts as a primer for Snf7/CHMP4 homo-oligomerization into a filament like structure with an indeterminate number of Snf7/CHMP4 molecules. This structure is subsequently capped by Vps24/CHMP3, which recruits Vps2/CHMP2. The Snf7/CHMP4 filament creates a closed structure that sequesters ubiquitylated proteins inside and initiates invagination (Muzioł, et al. 2006). In yeast, it has been shown that ESCRTIII also serves as a scaffold for the Bro1/ALIXDoa4 deubiquitylation machinery that recycles ubiquitin from MVB cargoes before vesicle formation (Luhtala and Odorizzi 2004). In mammals, the deubiquitylating step is thought to be carried out by the ubiquitin-specific protease (USP) 8 and the AMSH (associated molecule with the $\underline{\mathrm{SH}} 3$ domain of STAM) DUBs (Wright, et al. 2011).

Finally, the Vps4/SKD1 (suppressor of $\underline{\mathrm{K}}^{+}$ transport growth defect) AAA ATPase binds to the Vps24/CHMP3-Vps2/CHMP2 dimer and forms a double ring-shaped octamer or hexamer, which upon activation by Vps46/CHMP1, disassembles the complex (Nickerson, et al. 2006, Rue, et al. 2008, Saksena, et al. 2009). Vps4/SKD1 activity is also regulated by other components. For example, Vta1/LIP5 (lystinteracting protein 5) and its interacting protein, Vps60/CHMP5, have been shown to activate Vps4/SKD1 in yeast (Azmi, et al. 2008).

Evidence suggests that ESCRT-III components have several functions. For example, ESCRT-III components were independently discovered in humans as proteins affecting chromatin structure and cell cycle progression and were named 
"CHMP" (initially chromatin modifying protein, later charged multivesicular body protein) (Stauffer, et al. 2001). The role of ESCRT-III in chromatin remodeling is far less characterized, but recently it has been shown that one isoform, CHMP1A is required for cerebellar development, possibly by functioning as a link between cytoplasmic signals and chromatin modifications (Mochida, et al. 2012). Additionally, ESCRT-III was shown to play a role in cytokinetic abscission (Lafaurie-Janvore, et al. 2013, Wollert, et al. 2009). In yeast, ESCRT-III components were also found to be extragenic suppressors of a mutation in the deubiquitylating enzyme Doa4, so were also named DID (doaindependent degradation) (Amerik, et al. 2000). Snf7, one of the ESCRT-III components, was initially identified as a sucrose non-fermenting gene due to its effect on $\bar{S} U C 2$ expression, which encodes the yeast invertase enzyme (Vallier and Carlson 1991). The ESCRT-II component, Vps22 (also known as Snf8) was also identified in this screen. Finally, ESCRT components were also shown to play a role in the yeast alkaline response, or Rim101, pathway (Hayashi, et al. 2005).

In some cases, trafficking through the MVB has an essential role in signal transduction. For instance, ESCRT-III has been shown to affect mammalian TORC1 activation and signaling (Flinn, et al. 2010). This could also be a means of regulating ion fluxes, as TOR signaling has been related to salt stress in yeast (Crespo, et al. 2001, Mulet, et al. 2006).

Interestingly, although the standard fate of MVB is to fuse with the lysosome /vacuole for degradation, there is an alternative pathway that fuses the MVB with the plasma membrane and releases the intralumenal vesicles to the extracellular media in the form of exosomes. It has recently been shown that ESCRT function is required for exosome formation (Baietti, et al. 2012). No markers have been defined to distinguish between lysosomal-destined MVBs and MVBs used for secretion, but it is known that RAB26A, RAB27B, RAB35 and ceramide are required for exosome targeting and docking at the plasma membrane (Hsu, et al. 2010, Ostrowski, et al. 2010, Trajkovic, et al. 2006). In plants, there is an additional organelle that controls exocytosis, the EXPO (exocyst positive organelles). This organelle releases single membrane vesicles into the cell wall, but no relation with the MVB has been shown (Wang, et al. 2010).

\section{Plants}

Most of the data regarding endosomal trafficking and transport protein endocytosis comes from yeast or animal models. Initial data from genome projects indicate that the ESCRT machinery is largely conserved in plants (Winter and Hauser 2006). However, it is important to point out that the endosomal system is different in plants and animals. There are only two endosomal organelles that have been clearly identified and characterized: TGN/TGN-derived vesicles that act as recycling early endosomes and the late endosomes or MVB, also called pre-vacuolar compartments (Reyes, et al. 2011). The tubulovesicular early endosomes responsible for receptor recycling found in mammals, have not been observed in plants (Otegui and Spitzer 2008), although there is a description in the literature of tubular-vesicular structures in the plant TGN (Lam, et al. 2007). In general, there is much less information available on the molecular function of ESCRT components and the endocytic pathway in plants as compared to other organisms. However, it is interesting to note that some key features, such as the role of ESCRT in cytokinesis, were first described in plants. The characterization of the cytokinesis defect of the elch mutant in Arabidopsis thaliana showed that this gene encodes the plant orthologue of ESCRT-I component, Vps23/TSG101, which in Arabidopsis is called AtELC (Spitzer, et al. 2006).

ESCRT-0 components are not conserved in plants, although there are plant proteins that contain structural motifs common to this family of proteins (i.e. FYVE domains) and thus may carry out this function (Winter and Hauser 2006). The first ESCRT component described in plants was SAL1 (supernumerary aleurone layer 1) in maize. This orthologue of the ESCRT-IIIassociated component, Vps46/CHMP1, was identified for its function in determining the number of aleurone cell layers in endosperm (Shen, et al. 2003). Interestingly, a knockout of the ESCRT-II component, OsVPS22 in rice also causes an abnormal endosperm and early seedling lethality, suggesting that endosome trafficking in plants is required for proper seed development (Zhang, et al. 2013). In fact SAL1, and presumably all components of the ESCRT machinery, are required to maintain proper plasma membrane concentrations of both DEK1 and CRINKLY, proteins essential for aleurone formation in maize (Tian, et al. 2007). Silencing of the Nicotiana benthamiana Vps46/CHMP1 orthologue, called NbCHMP1, has only a mild leaf morphology phenotype, but a double chmpla chmplb Arabidopsis thaliana mutant is defective in embryo development, dying after germination (Spitzer, et al. 2009, Yang, et al. 2004). This mutant accumulates proteins in the PM, including the auxin receptors PIN1, PIN2 and AUX1, resulting in a defect in the formation of the auxin gradient. 
In Arabidopsis, the role of the orthologue of the AAA ATPase Vps4/SKD1 (named AtSKD1) in MVB function has been established (Haas, et al. 2007). The expression of AtSKD1 ATPasedeficient mutants leads to alterations in the endosomes in both Nicotiana tabacum cell culture and transgenic Arabidopsis thaliana model systems. In this study, the Vta1/LIP5 orthologue, AtLIP5 was also identified as an AtSKD1 activating protein. There is also a proteomic report mapping the protein-protein interactions within ESCRT-III in Arabidopsis thaliana (Ibl, et al. 2012). In this study, a member of the Vps2 family of Arabidopsis, AtVPS2.2 was used as a bait to identify interacting proteins. As expected, AtSNF7.1 was identified, as were the ESCRT-III-associated components, AtVPS46.1/AtCHMP1B, AtVPS46.2/AtCHMP1A and AtVPS60.1.

\section{THE ROLE OF NHXI ALKALI METAL ANTIPORTERS IN ENDOCYTIC REGULATION}

Another factor connecting alkali metal regulation with endocytosis is the $\mathrm{Na}^{+}-\mathrm{K}^{+} / \mathrm{H}^{+}$antiporter Nhx1 (also known as Vps44). Originally identified as a class-E Vps mutant in yeast, Nhx1 was characterized as a $\mathrm{Na}^{+} / \mathrm{H}^{+}$antiporter localized in the vacuole and in the pre-vacuolar compartment (Nass, et al. 1997, Nass and Rao 1998, Raymond, et al. 1992). Nhx1 function is essential for proper protein sorting and it is essential for controlling the $\mathrm{pH}$ of the lumen of the MVB compartment (Bowers, et al. 2000, Brett, et al. 2005). Nhx1-mediated control of luminal $\mathrm{pH}$ is also essential for the first steps of vacuolar fusion (Qiu and Fratti 2010). In fact, it has been suggested that the function of Nhx1 in vesicular fusion may be parallel or posterior to MVB formation (Kallay, et al. 2011).

Yeast Nhx1 is conserved in plants (NHX) and animals (NHE). In animals there are nine isoforms, whose main function is the regulation of internal $\mathrm{pH}$ of cytoplasm and organellar lumens such as Golgi and post-Golgi (Nakamura, et al. 2005). A role for mammalian NHE transporters in endocytosis is not well characterized, but recently it has been shown that NHE6 is required for clathrin-dependent endocytosis of transferrin (Xinhan, et al. 2011). NHE8 has also been shown to regulate the morphology of late endosomes and affect protein trafficking. Silencing its expression in HeLa cells induced an increase in cell volume due to the accumulation of MVB, although the intralumenal $\mathrm{pH}$ of this aberrant MVB was normal, indicating that the main function of NHE8 is different from yeast Nhx1 (Lawrence, et al. 2010). The neuronspecific isoform, NHE5 is regulated by clathrinmediated endocytosis and recycling, depending on the phosphatidylinositol 3'-kinase and F-actin assembly (Szaszi, et al. 2002). The intestinal isoform NHE3 requires phosphorylation by SGK3 in the recycling endosome for acute activation by glucocorticoids (He, et al. 2011).

In the model plant Arabidopsis thaliana, there are 6 NHX orthologues (Rodríguez-Rosales, et al. 2009). AtNHXs are key determinants for abiotic stress tolerance, but are also required for potassium uptake into vacuoles to regulate cell turgor and stomatal function and regulate changes of petal color in some plants (Apse, et al. 1999, Barragán, et al. 2012, Yamaguchi, et al. 2001, Yoshida, et al. 2005). The role of plant NHX proteins in endocytic trafficking is not characterized, but it its known that in addition to its well-established function in ion homeostasis, different NHX genes are required to regulate growth, flower development and reproduction. Thus, these transporters may have pleiotropic functions (Bassil, et al. 2011).

\section{ENDOCYTIC TRAFFICKING AND DISEASE}

MVBs were originally discovered in yeast, but investigation in mammalian systems advanced rapidly due to the fact that the MVB machinery is hijacked by the HIV virus to egress from the cell. The PTAP-type primary L domain of HIV-1 binds to the ESCRT-I component TSG101 to recruit this complex. Additionally, an auxiliary LYPXmL-type L domain recruits the ESCRT-III binding partner, ALIX (Usami, et al. 2009). Ubiquitylation has a role in this process, as overexpression of Nedd4-2 bypasses the requirement to engage ESCRT-I in HIV-1 mutants lacking a TSG101-binding site (Usami, et al. 2008). It is also clear that not all components of the ESCRT machinery are required for virus assembly in the MVB and subsequent exocytosis. HIV-1 budding only requires TSG101 and/or ALIX, and a subset of ESCRT-III proteins (CHMP4, CHMP2 and SKD4) (Langelier, et al. 2006, Morita, et al. 2011).

Herpes simplex virus type I production also requires a functional ESCRT-III complex, but not ALIX or TSG101, whereas Ebola virus budding requires host Vps4/SKD1 activity, but can also bypass the requirement for the TSG101 ESCRT-I component (Pawliczek and Crump 2009, Silvestri, et al. 2007). The ESCRT complex has also been shown to restrict the growth of intracellular bacterial pathogens, such as Mycobacterium tuberculosis (Philips, et al. 2008). The mechanism is unknown, but it is thought to be due to alterations in lysosomal composition or trafficking routes. Moreover, Cryptococcus neoformans, the causative agent of fungal meningoencephalitis in HIV/AIDS patients, requires its $\mathrm{Vps} 23$ protein for both 
capsule formation and virulence $(\mathrm{Hu}$, et al. 2013).

In plants, tombusvirus, like the tomato bushy stunt virus, also hijacks the ESCRT machinery. In this case, the mechanism has been proposed to involve the ubiquitylation of the viral replication protein, p33. This viral protein was shown to interact with yeast ESCRT-I component, Vps23 in a ubiquitylation-dependent manner, thus suggesting that ESCRT recruitment by the virus occurs via this interaction (Barajas and Nagy 2010). Overexpression of dominant negative versions of AtVPS4/SKD1 and ESCRT-III components have been shown to interfere with tomato bushy stunt virus replication and assembly in plant models of viral infection, further supporting a role for ESCRT function in these processes (Barajas, et al. 2009).

The regulation of ion homeostasis by the ESCRT pathway can also be related to disease. As discussed above, $\mathrm{ENaC}$, the epithelial sodium channel implicated in the pathogenesis of Liddle's Syndrome, is ubiquitylated by Nedd4-2, endocytosed and targeted to the MVB for lysosomal degradation in response to different stimuli, including hormones. Recently, the ESCRT-0 component, Hrs was shown to mediate the lysosomal sorting of $\mathrm{ENaC}$, demonstrating the expected role of the ESCRT pathway in this process (Zhou, et al. 2010).

Interestingly, defects in MVB have been associated with several kidney diseases, indicating the pivotal role of this system in regulating ion and water fluxes. Mutant alleles of the aquaporin, AQP2, which accumulate in the MVB instead of the plasma membrane, cause nephrogenic diabetes insipidus (Kamsteeg, et al. 2008). Moreover, defects in MVB formation are used as biomarkers of focal segmental glomerulosclerosis (Kim, et al. 2003). This disease is caused by mutations in TRPC6, the non-selective cation channel involved in receptor-mediated calcium signaling. Recently it has been shown that the ESCRT-II component, EAP30, physically interacts with the cytoplasmic amino-terminal domain of TRPC6 and enhances its activity, but apparently in an ESCRTindependent manner as the amount of TRPC6 in the plasma membrane is not altered (Carrasquillo, et al. 2012).

There many other examples of ESCRT-related diseases. A mutation in the CHMP4 isoform, $\mathrm{CHMP} 4 \mathrm{~B}$, is the cause of one form of familiar cataracts and mutations in CHMP2B cause a class of amyotrophic lateral sclerosis and frontotemporal dementia (Parkinson, et al. 2006, Shiels, et al. 2007, Skibinski, et al. 2005). CHMP1B also interacts with the hereditary spastic paraplegia protein, spastin (Reid, et al. 2005).
Targeting receptors to the MVB is a way to modulate signals to maintain cellular homeostasis. MVB function has also been related to several kinds of cancer due to its role in the degradation of receptor tyrosine kinases and its involvement in cytokinesis. Accordingly, TSG101 has been found to be over-expressed in several cancers and Hrs over-expression is associated with malignancy (Toyoshima, et al. 2007, Tu, et al. 2011). Surprisingly, in other cases ESCRT loss-of-function, instead of overexpression, can lead to tumorigenesis. Specifically, mutations in isoforms of the ESCRT-I component, VPS37 have been related to hepatocellular carcinoma and ovarian cancer (Bache, et al. 2004, Wittinger, et al. 2011).

There are a few examples where the study of a disease may give new insights into ESCRT function. There is a recent report indicating that the small integral membrane protein of lysosome/late endosome (SIMPLE) co-localizes and interacts with ESCRT-0 and ESCRT-I components and is required for the recruitment of ESCRT components to the endosomal membrane (Lee, et al. 2012). Mutations in the SIMPLE protein cause the autosomal dominant type 1C Charcot-Marie-Tooth disease.

\section{CONCLUDING REMARKS}

The endocytic regulation of many mammalian alkali metal transporters has been welldocumented. In many cases, it is the Nedd4-2 E3 ubiquitin ligase which is responsible for this regulation (Rotin and Kumar 2009). Future studies will continue to elucidate the mechanisms through which Nedd4-2 associates with target proteins in a timely manner and continue define the physiological relevance under normal conditions and in disease states. In yeast, the Nedd4 orthologue, Rsp5, is the E3 ubiquitin ligase responsible for the regulation of the majority of plasma membrane proteins studied to date (Lauwers, et al. 2010). Although more studies are needed, initial data suggest that Rsp5, like Nedd4-2, may mediate the regulation of yeast alkali metal transport proteins, like the Trk $1 \mathrm{~K}^{+}$transporter.

In plants, the role of endocytic regulation is currently being established for many classes of transport proteins. It is clear that all major components of the ESCRT machinery are conserved and play important roles in many facets of plant physiology (Schellmann and Pimpl 2009). However, the Nedd4 family of E3 ubiquitin ligases is absent in plants, as are the $\alpha$ arrestin adaptor proteins (Alvarez 2008, Downes, et al. 2003). Therefore, although it is known that endocytic regulation of the alkali metal transporter KAT1 is important for processes like stomatal closure, the role of ubiquitylation 
remains to be determined (Eisenach, et al. 2012, Sutter, et al. 2007). Excess substrate-mediated and ligand-mediated ubiquitylation-dependent down-regulation has been described in plants, but future studies will be required to define the E3 ubiquitin ligases and signal transduction pathways involved in these processes (Kasai, et al. 2011, Lu, et al. 2011). Finally, more work will be required to fully characterize the remaining components of the plant ESCRT and endocytic machinery to define the mechanistic similarities and differences.

The next few years should bring exciting discoveries in these areas which are sure to have important impacts not only in basic science, but also in fields as diverse as channelopathies, plant abiotic stress tolerance and plant and animal viral infections.

\section{Acknowledgements}

This work was supported by grant BFU201130197-C03-03 from the Ministerio de Ciencia e Innovación (Spain). V. L.-T. is supported by a fellowship from the Universidad Politécnica de Valencia. C. P. is supported by a fellowship from the Consejo Superior de Investigaciones Científicas (Spain). 


\section{Tables}

\begin{tabular}{|lll|}
\hline TRANSPORTER & E3 Ub LIGASE & \multicolumn{1}{c|}{ REFERENCES } \\
\hline ENaC & Nedd4-2 & $\begin{array}{l}\text { (Abriel, et al. 1999, Kamynina, et al. 2001, Staub, et al. } \\
\text { 1996) }\end{array}$ \\
NavS, Nav1.2, Nav1.3, & Nedd4-2, & (Fotia, et al. 2004, Rougier, et al. 2005, van Bemmelen, \\
Nav1.5, Nav1.7, Nav1.8 & Nedd4/Nedd4-like & et al. 2004) \\
NCC & Nedd4-2 & (Arroyo, et al. 2011, Ronzaud, et al. 2013) \\
KCNQ1/KCNE1 & Nedd4-2 & (Jespersen, et al. 2007) \\
KCNQ2/3, KCNQ3/5 & Nedd4-2 & (Ekberg, et al. 2007, Schuetz, et al. 2008) \\
KCNA3/KCNA5 & Nedd4-2 & (Boehmer, et al. 2008, Henke, et al. 2004) \\
KCNJ2 & Nedd4-2 & (Alesutan, et al. 2011) \\
hERG & Nedd4-2 & (Guo, et al. 2012, Lamothe and Zhang 2013) \\
\hline
\end{tabular}

Table 1. Mammalian alkali metal transporters regulated by the Nedd4 family of E3 ubiquitin ligases.

\begin{tabular}{|c|c|c|c|c|}
\hline COMPLEX & FUNCTION & Yeast & $\begin{array}{l}\text { COMPONENT, } \\
\text { Humans }\end{array}$ & Plants \\
\hline \multirow[b]{2}{*}{ ESCRT-0 } & \multirow{2}{*}{$\begin{array}{l}\text { Initiation, target } \\
\text { protein recognition }\end{array}$} & Vps27 & Hrs & \\
\hline & & Hse 1 & $\begin{array}{l}\text { STAM1, } \\
\text { STAM2 }\end{array}$ & \\
\hline \multirow{4}{*}{ ESCRT-I } & \multirow{4}{*}{$\begin{array}{l}\text { Target protein } \\
\quad \text { sorting }\end{array}$} & Vps23 (Stp22) & TSG101 & AtELC \\
\hline & & Vps28 & VPS28 & \\
\hline & & Vps37 (Snr2) & $\begin{array}{l}\text { VPS37A, } \\
\text { VPS37B, } \\
\text { VPS37C } \\
\end{array}$ & \\
\hline & & Mvb12 & $\begin{array}{l}\text { hMVB12A, } \\
\text { hMVB12B }\end{array}$ & \\
\hline \multirow{3}{*}{ ESCRT-II } & \multirow{3}{*}{$\begin{array}{l}\text { Target protein } \\
\quad \text { sorting }\end{array}$} & Vps36 & EAP45 & \\
\hline & & Vps22 (Snf8) & EAP30 & OsVPS22 \\
\hline & & $\mathrm{Vps} 25$ & EAP20 & \\
\hline \multirow{4}{*}{ ESCRT-III } & \multirow{4}{*}{$\begin{array}{l}\text { Target protein } \\
\text { sequestering, } \\
\text { MVB formation }\end{array}$} & Vps20 & CHMP6 & \\
\hline & & Snf7 & $\begin{array}{l}\text { CHMP4A, } \\
\text { CHMP4B, } \\
\text { CHMP4C }\end{array}$ & AtSNF7.1 \\
\hline & & Vps24 & CHMP3 & \\
\hline & & Vps2 (Did4) & $\begin{array}{l}\text { CHMP2A, } \\
\text { CHMP2B }\end{array}$ & $\begin{array}{l}\text { AtVPS2.1 } \\
\text { AtVPS2.2 } \\
\text { AtVPS2.3 } \\
\end{array}$ \\
\hline \multirow{3}{*}{$\begin{array}{l}\text { Vps/Vta1 } \\
\text { complex }\end{array}$} & \multirow{3}{*}{$\begin{array}{c}\text { ESCRT } \\
\text { Disassembly }\end{array}$} & Vps4 & SKD1 & AtVPS4/SKD1 \\
\hline & & Vta1 & LIP5 & AtLIP5 \\
\hline & & Vps60 & CHMP5 & AtVPS60.1 \\
\hline \multirow{3}{*}{ Others } & Vps4 activation & Vps46 (Did2) & $\begin{array}{l}\text { CHMP1A, } \\
\text { CHMP1B }\end{array}$ & $\begin{array}{c}\text { NbCHMP1 } \\
\text { AtCHMP1A/AtVPS46.2 } \\
\text { AtCHMP1B/AtVPS46.1 } \\
\text { ZmSAL1 } \\
\end{array}$ \\
\hline & $\begin{array}{c}\text { ESCRT auxiliary } \\
\text { protein } \\
\end{array}$ & Bro1 & ALIX (AIP1) & \\
\hline & ESCRT-DUB & Doa4 & $\begin{array}{c}\text { USP8 (UBPY) and } \\
\text { AMSH }\end{array}$ & AtAMSH \\
\hline
\end{tabular}

Table 2. ESCRT component nomenclature. See text for references and details. We have opted for the use of commonly-used yeast names adopted in other species. If different, the standard Saccharomyces Genome Database names of yeast proteins are in parenthesis. Here, we have listed the plant proteins discussed here that have been characterized genetically or biochemically. 


\section{Figure Legends}

Figure 1. Schematic representation of examples of endocytic regulation of selected plasma membrane transport proteins in mammals, yeast and Arabidopsis thaliana. See text for details. (EE, early endosome; LE, late endosome; RE, recycling endosome).

Figure 2. Improved growth of rsp5 mutants in low-potassium media. Strains containing the wild type version or partial loss-of-function mutations in the RSP5 gene were grown to saturation, serially diluted in water and deposited on Translucent media plates supplemented with the indicated amount of $\mathrm{KCl}$ (Navarrete, et al. 2010). The rsp5 mutants harbor different point mutations in the HECT domain of the genomic copy of RSP5 (HPG: High Pressure Growth) (Abe and Iida 2003). Images were taken after 72 hours. Identical results were observed in three different experiments. 


\section{References}

Abe F, Iida H (2003) Pressure-induced differential regulation of the two tryptophan permeases Tat1 and Tat2 by ubiquitin ligase Rsp5 and its binding proteins, Bul1 and Bul2. Mol Cell Biol 23: 75667584 doi:

Abriel H, Loffing J, Rebhun JF, Pratt JH, Schild L, Horisberger JD, Rotin D, Staub O (1999) Defective regulation of the epithelial $\mathrm{Na}+$ channel by Nedd4 in Liddle's syndrome. J Clin Invest 103: 667673 doi: 10.1172/JCI5713

Alesutan I, Munoz C, Sopjani M, Dërmaku-Sopjani M, Michael D, Fraser S, Kemp BE, Seebohm G, Föller M, Lang F (2011) Inhibition of Kir2.1 (KCNJ2) by the AMP-activated protein kinase. Biochem Biophys Res Commun 408: 505-510 doi: 10.1016/j.bbrc.2011.04.015

Alvarez CE (2008) On the origins of arrestin and rhodopsin. BMC Evol Biol 8: 222 doi: 10.1186/14712148-8-222

Amerik AY, Nowak J, Swaminathan S, Hochstrasser M (2000) The Doa4 deubiquitinating enzyme is functionally linked to the vacuolar protein-sorting and endocytic pathways. Mol Biol Cell 11: 3365-3380 doi:

Anderson JA, Huprikar SS, Kochian LV, Lucas WJ, Gaber RF (1992) Functional expression of a probable Arabidopsis thaliana potassium channel in Saccharomyces cerevisiae. Proc Natl Acad Sci U S A 89: 3736-3740 doi:

Anderson JA, Nakamura RL, Gaber RF (1994) Heterologous expression of K+ channels in Saccharomyces cerevisiae: strategies for molecular analysis of structure and function. Symp Soc Exp Biol 48: 85-97 doi:

Aniento F, Gu F, Parton RG, Gruenberg J (1996) An endosomal beta COP is involved in the pHdependent formation of transport vesicles destined for late endosomes. J Cell Biol 133: 29-41 doi:

Apse MP, Aharon GS, Snedden WA, Blumwald E (1999) Salt tolerance conferred by overexpression of a vacuolar $\mathrm{Na}+\mathrm{H}+$ antiport in Arabidopsis. Science 285: 1256-1258 doi:

Arino J, Ramos J, Sychrova H (2010) Alkali Metal Cation Transport and Homeostasis in Yeasts. Microbiology and Molecular Biology Reviews 74: 95-+ doi: 10.1128/mmbr.00042-09

Arnason TG, Pisclevich MG, Dash MD, Davies GF, Harkness TA (2005) Novel interaction between Apc5p and Rsp5p in an intracellular signaling pathway in Saccharomyces cerevisiae. Eukaryot Cell 4: 134-146 doi: 10.1128/EC.4.1.134-146.2005

Arroyo JP, Lagnaz D, Ronzaud C, Vázquez N, Ko BS, Moddes L, Ruffieux-Daidié D, Hausel P, Koesters R, Yang B, Stokes JB, Hoover RS, Gamba G, Staub O (2011) Nedd4-2 modulates renal Na+-Clcotransporter via the aldosterone-SGK1-Nedd4-2 pathway. J Am Soc Nephrol 22: 1707-1719 doi: 10.1681/ASN.2011020132

Azmi IF, Davies BA, Xiao J, Babst M, Xu Z, Katzmann DJ (2008) ESCRT-III family members stimulate Vps4 ATPase activity directly or via Vta1. Dev Cell 14: 50-61 doi: 10.1016/j.devcel.2007.10.021

Babst M, Katzmann DJ, Estepa-Sabal EJ, Meerloo T, Emr SD (2002a) Escrt-III: an endosome-associated heterooligomeric protein complex required for mvb sorting. Dev Cell 3: 271-282 doi:

Babst M, Katzmann DJ, Snyder WB, Wendland B, Emr SD (2002b) Endosome-associated complex, ESCRT-II, recruits transport machinery for protein sorting at the multivesicular body. Dev Cell 3: 283-289 doi:

Bache KG, Slagsvold T, Cabezas A, Rosendal KR, Raiborg C, Stenmark H (2004) The growth-regulatory protein HCRP1/hVps37A is a subunit of mammalian ESCRT-I and mediates receptor downregulation. Mol Biol Cell 15: 4337-4346 doi: 10.1091/mbc.E04-03-0250

Baietti MF, Zhang Z, Mortier E, Melchior A, Degeest G, Geeraerts A, Ivarsson Y, Depoortere F, Coomans C, Vermeiren E, Zimmermann P, David G (2012) Syndecan-syntenin-ALIX regulates the biogenesis of exosomes. Nat Cell Biol 14: 677-685 doi: 10.1038/ncb2502

Barajas D, Jiang Y, Nagy PD (2009) A unique role for the host ESCRT proteins in replication of Tomato bushy stunt virus. PLoS Pathog 5: e1000705 doi: 10.1371/journal.ppat.1000705

Barajas D, Nagy PD (2010) Ubiquitination of tombusvirus p33 replication protein plays a role in virus replication and binding to the host Vps23p ESCRT protein. Virology 397: 358-368 doi: 10.1016/j.virol.2009.11.010

Barberon M, Zelazny E, Robert S, Conéjéro G, Curie C, Friml J, Vert G (2011) Monoubiquitin-dependent endocytosis of the iron-regulated transporter 1 (IRT1) transporter controls iron uptake in plants. Proc Natl Acad Sci U S A 108: E450-458 doi: 10.1073/pnas.1100659108

Barragán V, Leidi EO, Andrés Z, Rubio L, De Luca A, Fernández JA, Cubero B, Pardo JM (2012) Ion exchangers NHX1 and NHX2 mediate active potassium uptake into vacuoles to regulate cell 
turgor and stomatal function in Arabidopsis. Plant Cell 24: 1127-1142 doi: 10.1105/tpc. 111.095273

Bassil E, Ohto MA, Esumi T, Tajima H, Zhu Z, Cagnac O, Belmonte M, Peleg Z, Yamaguchi T, Blumwald E (2011) The Arabidopsis intracellular Na+/H+ antiporters NHX5 and NHX6 are endosome associated and necessary for plant growth and development. Plant Cell 23: 224-239 doi: $10.1105 /$ tpc. 110.079426

Beaudenon SL, Huacani MR, Wang G, McDonnell DP, Huibregtse JM (1999) Rsp5 ubiquitin-protein ligase mediates DNA damage-induced degradation of the large subunit of RNA polymerase II in Saccharomyces cerevisiae. Mol Cell Biol 19: 6972-6979 doi:

Becuwe M, Vieira N, Lara D, Gomes-Rezende J, Soares-Cunha C, Casal M, Haguenauer-Tsapis R, Vincent O, Paiva S, Léon S (2012) A molecular switch on an arrestin-like protein relays glucose signaling to transporter endocytosis. J Cell Biol 196: 247-259 doi: 10.1083/jcb.201109113

Belgareh-Touzé N, Léon S, Erpapazoglou Z, Stawiecka-Mirota M, Urban-Grimal D, Haguenauer-Tsapis $\mathrm{R}$ (2008) Versatile role of the yeast ubiquitin ligase Rsp5p in intracellular trafficking. Biochem Soc Trans 36: 791-796 doi: 10.1042/BST0360791

Bhalla V, Oyster NM, Fitch AC, Wijngaarden MA, Neumann D, Schlattner U, Pearce D, Hallows KR (2006) AMP-activated kinase inhibits the epithelial $\mathrm{Na}+$ channel through functional regulation of the ubiquitin ligase Nedd4-2. J Biol Chem 281: 26159-26169 doi: 10.1074/jbc.M606045200

Blondel MO, Morvan J, Dupre S, Urban-Grimal D, Haguenauer-Tsapis R, Volland C (2004) Direct sorting of the yeast uracil permease to the endosomal system is controlled by uracil binding and Rsp5p-dependent ubiquitylation. Molecular Biology of the Cell 15: 883-895 doi: 10.1091/mbc.E03-04-0202

Boase NA, Rychkov GY, Townley SL, Dinudom A, Candi E, Voss AK, Tsoutsman T, Semsarian C, Melino G, Koentgen F, Cook DI, Kumar S (2011) Respiratory distress and perinatal lethality in Nedd4-2-deficient mice. Nat Commun 2: 287 doi: 10.1038/ncomms1284

Boehmer C, Laufer J, Jeyaraj S, Klaus F, Lindner R, Lang F, Palmada M (2008) Modulation of the voltage-gated potassium channel Kv1.5 by the SGK1 protein kinase involves inhibition of channel ubiquitination. Cell Physiol Biochem 22: 591-600 doi: 10.1159/000185543

Bonifacino JS, Traub LM (2003) Signals for sorting of transmembrane proteins to endosomes and lysosomes. Annu Rev Biochem 72: 395-447 doi: 10.1146/annurev.biochem.72.121801.161800

Bowers K, Levi BP, Patel FI, Stevens TH (2000) The sodium/proton exchanger Nhx1p is required for endosomal protein trafficking in the yeast Saccharomyces cerevisiae. Mol Biol Cell 11: 42774294 doi:

Brett CL, Tukaye DN, Mukherjee S, Rao R (2005) The yeast endosomal Na+K+/H+ exchanger Nhx1 regulates cellular $\mathrm{pH}$ to control vesicle trafficking. Mol Biol Cell 16: 1396-1405 doi: 10.1091/mbc.E04-11-0999

Brodsky JL (2012) Cleaning up: ER-associated degradation to the rescue. Cell 151: 1163-1167 doi: 10.1016/j.cell.2012.11.012

Cao XR, Lill NL, Boase N, Shi PP, Croucher DR, Shan H, Qu J, Sweezer EM, Place T, Kirby PA, Daly RJ, Kumar S, Yang B (2008) Nedd4 controls animal growth by regulating IGF-1 signaling. Sci Signal 1: ra5 doi: 10.1126/scisignal.1160940

Carrasquillo R, Tian D, Krishna S, Pollak MR, Greka A, Schlöndorff J (2012) SNF8, a member of the ESCRT-II complex, interacts with TRPC6 and enhances its channel activity. BMC Cell Biol 13: 33 doi: 10.1186/1471-2121-13-33

Chen L, Hellmann H (2013) PLANT E3 LIGASES: FLEXIBLE ENZYMES IN A SESSILE WORLD1. Mol Plant 10.1093/mp/sst005

Chinchilla D, Zipfel C, Robatzek S, Kemmerling B, Nürnberger T, Jones JD, Felix G, Boller T (2007) A flagellin-induced complex of the receptor FLS2 and BAK1 initiates plant defence. Nature 448: 497-500 doi: 10.1038/nature05999

Christie KJ, Martinez JA, Zochodne DW (2012) Disruption of E3 ligase NEDD4 in peripheral neurons interrupts axon outgrowth: Linkage to PTEN. Mol Cell Neurosci 50: 179-192 doi: 10.1016/j.men.2012.04.006

Clague MJ, Liu H, Urbé S (2012) Governance of endocytic trafficking and signaling by reversible ubiquitylation. Dev Cell 23: 457-467 doi: 10.1016/j.devcel.2012.08.011

Clancy JL, Henderson MJ, Russell AJ, Anderson DW, Bova RJ, Campbell IG, Choong DY, Macdonald GA, Mann GJ, Nolan T, Brady G, Olopade OI, Woollatt E, Davies MJ, Segara D, Hacker NF, Henshall SM, Sutherland RL, Watts CK (2003) EDD, the human orthologue of the hyperplastic discs tumour suppressor gene, is amplified and overexpressed in cancer. Oncogene 22: 50705081 doi: 10.1038/sj.onc. 1206775 
Coonrod EM, Stevens TH (2010) The yeast vps class E mutants: the beginning of the molecular genetic analysis of multivesicular body biogenesis. Mol Biol Cell 21: 4057-4060 doi: 10.1091/mbc.E0907-0603

Crespo JL, Daicho K, Ushimaru T, Hall MN (2001) The GATA transcription factors GLN3 and GAT1 link TOR to salt stress in Saccharomyces cerevisiae. Journal of Biological Chemistry 276: 34441-34444 doi: 10.1074/jbc.M103601200

Debonneville C, Flores SY, Kamynina E, Plant PJ, Tauxe C, Thomas MA, Münster C, Chraïbi A, Pratt JH, Horisberger JD, Pearce D, Loffing J, Staub O (2001) Phosphorylation of Nedd4-2 by Sgk1 regulates epithelial $\mathrm{Na}(+)$ channel cell surface expression. EMBO J 20: $7052-7059$ doi: 10.1093/emboj/20.24.7052

Downes BP, Stupar RM, Gingerich DJ, Vierstra RD (2003) The HECT ubiquitin-protein ligase (UPL) family in Arabidopsis: UPL3 has a specific role in trichome development. Plant J 35: 729-742 doi:

Eisenach C, Chen ZH, Grefen C, Blatt MR (2012) The trafficking protein SYP121 of Arabidopsis connects programmed stomatal closure and $\mathrm{K}^{+}$channel activity with vegetative growth. Plant $\mathrm{J}$ 69: 241-251 doi: 10.1111/j.1365-313X.2011.04786.x

Ekberg J, Schuetz F, Boase NA, Conroy SJ, Manning J, Kumar S, Poronnik P, Adams DJ (2007) Regulation of the voltage-gated $\mathrm{K}(+)$ channels KCNQ2/3 and KCNQ3/5 by ubiquitination. Novel role for Nedd4-2. J Biol Chem 282: 12135-12142 doi: 10.1074/jbc.M609385200

Faresse N, Lagnaz D, Debonneville A, Ismailji A, Maillard M, Fejes-Toth G, Náray-Fejes-Tóth A, Staub O (2012) Inducible kidney-specific Sgk1 knockout mice show a salt-losing phenotype. Am J Physiol Renal Physiol 302: F977-985 doi: 10.1152/ajprenal.00535.2011

Field MC, Gabernet-Castello C, Dacks JB (2007) Reconstructing the evolution of the endocytic system: insights from genomics and molecular cell biology. Adv Exp Med Biol 607: 84-96 doi: 10.1007/978-0-387-74021-8_7

Fisk HA, Yaffe MP (1999) A role for ubiquitination in mitochondrial inheritance in Saccharomyces cerevisiae. J Cell Biol 145: 1199-1208 doi:

Flinn RJ, Yan Y, Goswami S, Parker PJ, Backer JM (2010) The late endosome is essential for mTORC1 signaling. Mol Biol Cell 21: 833-841 doi: 10.1091/mbc.E09-09-0756

Fotia AB, Ekberg J, Adams DJ, Cook DI, Poronnik P, Kumar S (2004) Regulation of neuronal voltagegated sodium channels by the ubiquitin-protein ligases Nedd4 and Nedd4-2. J Biol Chem 279: 28930-28935 doi: 10.1074/jbc.M402820200

Futter CE, White IJ (2007) Annexins and endocytosis. Traffic 8: 951-958 doi: 10.1111/j.16000854.2007.00590.x

Gabriely G, Kama R, Gerst JE (2007) Involvement of specific COPI subunits in protein sorting from the late endosome to the vacuole in yeast. Mol Cell Biol 27: 526-540 doi: 10.1128/MCB.00577-06

Gajewska B, Shcherbik N, Oficjalska D, Haines DS, Zoladek T (2003) Functional analysis of the human orthologue of the RSP5-encoded ubiquitin protein ligase, hNedd4, in yeast. Current Genetics 43: 1-10 doi: 10.1007/s00294-003-0371-X

Galan JM, Moreau V, Andre B, Volland C, Haguenauer-Tsapis R (1996) Ubiquitination mediated by the Npi1p/Rsp5p ubiquitin-protein ligase is required for endocytosis of the yeast uracil permease. J Biol Chem 271: 10946-10952 doi:

Gao T, Liu Z, Wang Y, Cheng H, Yang Q, Guo A, Ren J, Xue Y (2013) UUCD: a family-based database of ubiquitin and ubiquitin-like conjugation. Nucleic Acids Res 41: D445-451 doi: 10.1093/nar/gks1103

Geldner N (2004) The plant endosomal system--its structure and role in signal transduction and plant development. Planta 219: 547-560 doi: 10.1007/s00425-004-1302-X

Gitan RS, Eide DJ (2000) Zinc-regulated ubiquitin conjugation signals endocytosis of the yeast ZRT1 zinc transporter. Biochemical Journal 346: 329-336 doi: 10.1042/0264-6021:3460329

Gitan RS, Luo H, Rodgers J, Broderius M, Eide D (1998) Zinc-induced inactivation of the yeast ZRT1 zinc transporter occurs through endocytosis and vacuolar degradation. J Biol Chem 273: 2861728624 doi:

Gong X, Chang A (2001) A mutant plasma membrane ATPase, Pma1-10, is defective in stability at the yeast cell surface. Proc Natl Acad Sci U S A 98: 9104-9109 doi: 10.1073/pnas.161282998

Guo J, Wang T, Li X, Shallow H, Yang T, Li W, Xu J, Fridman MD, Yang X, Zhang S (2012) Cell surface expression of human ether-a-go-go-related gene (hERG) channels is regulated by caveolin-3 protein via the ubiquitin ligase Nedd4-2. J Biol Chem 287: 33132-33141 doi: 10.1074/jbc.M112.389643 
Gwizdek C, Hobeika M, Kus B, Ossareh-Nazari B, Dargemont C, Rodriguez MS (2005) The mRNA nuclear export factor Hpr1 is regulated by Rsp5-mediated ubiquitylation. J Biol Chem 280: 13401-13405 doi: 10.1074/jbc.C500040200

Gómez-Gómez L, Boller T (2000) FLS2: an LRR receptor-like kinase involved in the perception of the bacterial elicitor flagellin in Arabidopsis. Mol Cell 5: 1003-1011 doi:

Haas TJ, Sliwinski MK, Martínez DE, Preuss M, Ebine K, Ueda T, Nielsen E, Odorizzi G, Otegui MS (2007) The Arabidopsis AAA ATPase SKD1 is involved in multivesicular endosome function and interacts with its positive regulator LYST-INTERACTING PROTEIN5. Plant Cell 19: 1295-1312 doi: 10.1105/tpc.106.049346

Hampton RY, Sommer T (2012) Finding the will and the way of ERAD substrate retrotranslocation. Curr Opin Cell Biol 24: 460-466 doi: 10.1016/j.ceb.2012.05.010

Harkness TA, Davies GF, Ramaswamy V, Arnason TG (2002) The ubiquitin-dependent targeting pathway in Saccharomyces cerevisiae plays a critical role in multiple chromatin assembly regulatory steps. Genetics 162: 615-632 doi:

Hasenbrink G, Schwarzer S, Kolacna L, Ludwig J, Sychrova H, Lichtenberg-Fraté H (2005) Analysis of the mKir2.1 channel activity in potassium influx defective Saccharomyces cerevisiae strains determined as changes in growth characteristics. FEBS Lett 579: 1723-1731 doi: 10.1016/j.febslet.2005.02.025

Hatakeyama R, Kamiya M, Takahara T, Maeda T (2010) Endocytosis of the aspartic acid/glutamic acid transporter Dip5 is triggered by substrate-dependent recruitment of the Rsp5 ubiquitin ligase via the arrestin-like protein Aly2. Mol Cell Biol 30: 5598-5607 doi: 10.1128/MCB.00464-10

Hayashi M, Fukuzawa T, Sorimachi H, Maeda T (2005) Constitutive activation of the pH-responsive Rim101 pathway in yeast mutants defective in late steps of the MVB/ESCRT pathway. Molecular and Cellular Biology 25: 9478-9490 doi: 10.1128/mcb.25.21.9478-9490.2005

He P, Lee SJ, Lin S, Seidler U, Lang F, Fejes-Toth G, Naray-Fejes-Toth A, Yun CC (2011) Serum- and glucocorticoid-induced kinase 3 in recycling endosomes mediates acute activation of $\mathrm{Na}+\mathrm{H}+$ exchanger NHE3 by glucocorticoids. Mol Biol Cell 22: 3812-3825 doi: 10.1091/mbc.E11-040328

Heese A, Hann DR, Gimenez-Ibanez S, Jones AM, He K, Li J, Schroeder JI, Peck SC, Rathjen JP (2007) The receptor-like kinase SERK3/BAK1 is a central regulator of innate immunity in plants. Proc Natl Acad Sci U S A 104: 12217-12222 doi: 10.1073/pnas.0705306104

Hein C, Springael JY, Volland C, Haguenauer-Tsapis R, André B (1995) NP11, an essential yeast gene involved in induced degradation of Gap1 and Fur4 permeases, encodes the Rsp5 ubiquitinprotein ligase. Mol Microbiol 18: 77-87 doi:

Henke G, Maier G, Wallisch S, Boehmer C, Lang F (2004) Regulation of the voltage gated K+ channel Kv1.3 by the ubiquitin ligase Nedd4-2 and the serum and glucocorticoid inducible kinase SGK1. J Cell Physiol 199: 194-199 doi: 10.1002/jcp.10430

Herberth S, Shahriari M, Bruderek M, Hessner F, Müller B, Hülskamp M, Schellmann S (2012) Artificial ubiquitylation is sufficient for sorting of a plasma membrane ATPase to the vacuolar lumen of Arabidopsis cells. Planta 236: 63-77 doi: 10.1007/s00425-012-1587-0

Hicke L, Dunn R (2003) Regulation of membrane protein transport by ubiquitin and ubiquitin-binding proteins. Annu Rev Cell Dev Biol 19: 141-172 doi: 10.1146/annurev.cellbio.19.110701.154617

Hicke L, Riezman H (1996) Ubiquitination of a yeast plasma membrane receptor signals its ligandstimulated endocytosis. Cell 84: 277-287 doi:

Hicke L, Zanolari B, Riezman H (1998) Cytoplasmic tail phosphorylation of the alpha-factor receptor is required for its ubiquitination and internalization. J Cell Biol 141: 349-358 doi:

Hoppe T, Matuschewski K, Rape M, Schlenker S, Ulrich HD, Jentsch S (2000) Activation of a membrane-bound transcription factor by regulated ubiquitin/proteasome-dependent processing. Cell 102: 577-586 doi:

Hsu C, Morohashi Y, Yoshimura S, Manrique-Hoyos N, Jung S, Lauterbach MA, Bakhti M, Grønborg M, Möbius W, Rhee J, Barr FA, Simons M (2010) Regulation of exosome secretion by Rab35 and its GTPase-activating proteins TBC1D10A-C. J Cell Biol 189: 223-232 doi: 10.1083/jcb.200911018

Hu G, Caza M, Cadieux B, Chan V, Liu V, Kronstad J (2013) Cryptococcus neoformans requires the ESCRT protein Vps23 for iron acquisition from heme, for capsule formation, and for virulence. Infect Immun 81: 292-302 doi: 10.1128/IAI.01037-12

Huang F, Goh LK, Sorkin A (2007) EGF receptor ubiquitination is not necessary for its internalization. Proc Natl Acad Sci U S A 104: 16904-16909 doi: 10.1073/pnas.0707416104 
Huang F, Kirkpatrick D, Jiang X, Gygi S, Sorkin A (2006) Differential regulation of EGF receptor internalization and degradation by multiubiquitination within the kinase domain. Mol Cell 21: 737-748 doi: 10.1016/j.molcel.2006.02.018

Huibregtse JM, Scheffner M, Beaudenon S, Howley PM (1995) A family of proteins structurally and functionally related to the E6-AP ubiquitin-protein ligase. Proc Natl Acad Sci U S A 92: 25632567 doi:

Hurst AC, Meckel T, Tayefeh S, Thiel G, Homann U (2004) Trafficking of the plant potassium inward rectifier KAT1 in guard cell protoplasts of Vicia faba. Plant J 37: 391-397 doi:

Husnjak K, Dikic I (2012) Ubiquitin-binding proteins: decoders of ubiquitin-mediated cellular functions. Annu Rev Biochem 81: 291-322 doi: 10.1146/annurev-biochem-051810-094654

Ibl V, Csaszar E, Schlager N, Neubert S, Spitzer C, Hauser MT (2012) Interactome of the plant-specific ESCRT-III component AtVPS2.2 in Arabidopsis thaliana. J Proteome Res 11: 397-411 doi: $10.1021 / \mathrm{pr} 200845 \mathrm{n}$

Ichimura T, Yamamura H, Sasamoto K, Tominaga Y, Taoka M, Kakiuchi K, Shinkawa T, Takahashi N, Shimada S, Isobe T (2005) 14-3-3 proteins modulate the expression of epithelial Na+ channels by phosphorylation-dependent interaction with Nedd4-2 ubiquitin ligase. J Biol Chem 280: 13187-13194 doi: 10.1074/jbc.M412884200

Jegla TJ, Zmasek CM, Batalov S, Nayak SK (2009) Evolution of the human ion channel set. Comb Chem High Throughput Screen 12: 2-23 doi:

Jenness DD, Li Y, Tipper C, Spatrick P (1997) Elimination of defective alpha-factor pheromone receptors. Mol Cell Biol 17: 6236-6245 doi:

Jespersen T, Membrez M, Nicolas CS, Pitard B, Staub O, Olesen SP, Baró I, Abriel H (2007) The KCNQ1 potassium channel is down-regulated by ubiquitylating enzymes of the Nedd4/Nedd4like family. Cardiovasc Res 74: 64-74 doi: 10.1016/j.cardiores.2007.01.008

Jolliffe CN, Harvey KF, Haines BP, Parasivam G, Kumar S (2000) Identification of multiple proteins expressed in murine embryos as binding partners for the WW domains of the ubiquitin-protein ligase Nedd4. Biochem J 351 Pt 3: 557-565 doi:

Kallay LM, Brett CL, Tukaye DN, Wemmer MA, Chyou A, Odorizzi G, Rao R (2011) Endosomal Na+ $(\mathrm{K}+) / \mathrm{H}+$ exchanger Nhx1/Vps44 functions independently and downstream of multivesicular body formation. J Biol Chem 286: 44067-44077 doi: 10.1074/jbc.M111.282319

Kamsteeg EJ, Savelkoul PJ, Hendriks G, Konings IB, Nivillac NM, Lagendijk AK, van der Sluijs P, Deen PM (2008) Missorting of the Aquaporin-2 mutant E258K to multivesicular bodies/lysosomes in dominant NDI is associated with its monoubiquitination and increased phosphorylation by PKC but is due to the loss of E258. Pflugers Arch 455: 1041-1054 doi: 10.1007/s00424-007-0364-6

Kamynina E, Debonneville C, Bens M, Vandewalle A, Staub O (2001) A novel mouse Nedd4 protein suppresses the activity of the epithelial Na+ channel. FASEB J 15: 204-214 doi: 10.1096/fj.000191com

Kasai K, Takano J, Miwa K, Toyoda A, Fujiwara T (2011) High boron-induced ubiquitination regulates vacuolar sorting of the BOR1 borate transporter in Arabidopsis thaliana. J Biol Chem 286: 61756183 doi: 10.1074/jbc.M110.184929

Katzmann DJ, Babst M, Emr SD (2001) Ubiquitin-dependent sorting into the multivesicular body pathway requires the function of a conserved endosomal protein sorting complex, ESCRT-I. Cell 106: $145-155$ doi:

Katzmann DJ, Stefan CJ, Babst M, Emr SD (2003) Vps27 recruits ESCRT machinery to endosomes during MVB sorting. J Cell Biol 162: 413-423 doi: 10.1083/jcb.200302136

Kim JM, Wu H, Green G, Winkler CA, Kopp JB, Miner JH, Unanue ER, Shaw AS (2003) CD2associated protein haploinsufficiency is linked to glomerular disease susceptibility. Science 300: 1298-1300 doi: 10.1126/science. 1081068

Kim TH, Böhmer M, Hu H, Nishimura N, Schroeder JI (2010) Guard cell signal transduction network: advances in understanding abscisic acid, $\mathrm{CO} 2$, and Ca2+ signaling. Annu Rev Plant Biol 61: 561-591 doi: 10.1146/annurev-arplant-042809-112226

Komander D, Rape M (2012) The ubiquitin code. Annu Rev Biochem 81: 203-229 doi: 10.1146/annurevbiochem-060310-170328

Kulathu Y, Komander D (2012) Atypical ubiquitylation - the unexplored world of polyubiquitin beyond Lys48 and Lys63 linkages. Nat Rev Mol Cell Biol 13: 508-523 doi: 10.1038/nrm3394

Kullmann DM (2010) Neurological channelopathies. Annu Rev Neurosci 33: 151-172 doi: 10.1146/annurev-neuro-060909-153122

Kumar S, Harvey KF, Kinoshita M, Copeland NG, Noda M, Jenkins NA (1997) cDNA cloning, expression analysis, and mapping of the mouse Nedd4 gene. Genomics 40: 435-443 doi: 10.1006/geno.1996.4582 
Kumar S, Tomooka Y, Noda M (1992) Identification of a set of genes with developmentally downregulated expression in the mouse brain. Biochem Biophys Res Commun 185: 1155-1161 doi:

Kölling R, Hollenberg CP (1994) The ABC-transporter Ste6 accumulates in the plasma membrane in a ubiquitinated form in endocytosis mutants. EMBO J 13: 3261-3271 doi:

Lafaurie-Janvore J, Maiuri P, Wang I, Pinot M, Manneville JB, Betz T, Balland M, Piel M (2013) ESCRT-III assembly and cytokinetic abscission are induced by tension release in the intercellular bridge. Science 339: 1625-1629 doi: 10.1126/science. 1233866

Lam SK, Siu CL, Hillmer S, Jang S, An G, Robinson DG, Jiang L (2007) Rice SCAMP1 defines clathrincoated, trans-golgi-located tubular-vesicular structures as an early endosome in tobacco BY-2 cells. Plant Cell 19: 296-319 doi: 10.1105/tpc.106.045708

Lamothe S, Zhang S (2013) The Serum- and Glucocorticoid-Inducible Kinase SGK1 and SGK3 Regulate hERG Channel Expression via Ubiquitin Ligase Nedd4-2 and GTPase Rab11. J Biol Chem 10.1074/jbc.M113.453670

Langelier C, von Schwedler UK, Fisher RD, De Domenico I, White PL, Hill CP, Kaplan J, Ward D, Sundquist WI (2006) Human ESCRT-II complex and its role in human immunodeficiency virus type 1 release. J Virol 80: 9465-9480 doi: 10.1128/JVI.01049-06

Lauwers E, Erpapazoglou Z, Haguenauer-Tsapis R, André B (2010) The ubiquitin code of yeast permease trafficking. Trends Cell Biol 20: 196-204 doi: 10.1016/j.tcb.2010.01.004

Lawrence SP, Bright NA, Luzio JP, Bowers K (2010) The sodium/proton exchanger NHE8 regulates late endosomal morphology and function. Mol Biol Cell 21: 3540-3551 doi: 10.1091/mbc.E09-121053

Lee KB, Ptasienski JA, Bunemann M, Hosey MM (2000) Acidic amino acids flanking phosphorylation sites in the M2 muscarinic receptor regulate receptor phosphorylation, internalization, and interaction with arrestins. J Biol Chem 275: 35767-35777 doi: 10.1074/jbc.M002225200

Lee SM, Chin LS, Li L (2012) Charcot-Marie-Tooth disease-linked protein SIMPLE functions with the ESCRT machinery in endosomal trafficking. J Cell Biol 199: 799-816 doi: $10.1083 /$ jcb. 201204137

Lefkowitz RJ, Rajagopal K, Whalen EJ (2006) New roles for beta-arrestins in cell signaling: not just for seven-transmembrane receptors. Mol Cell 24: 643-652 doi: 10.1016/j.molcel.2006.11.007

Lin CH, MacGurn JA, Chu T, Stefan CJ, Emr SD (2008) Arrestin-related ubiquitin-ligase adaptors regulate endocytosis and protein turnover at the cell surface. Cell 135: 714-725 doi: 10.1016/j.cell.2008.09.025

Liu J, Sitaram A, Burd CG (2007) Regulation of copper-dependent endocytosis and vacuolar degradation of the yeast copper transporter, Ctr1p, by the Rsp5 ubiquitin ligase. Traffic 8: 1375-1384 doi: 10.1111/j.1600-0854.2007.00616.x

Liu Y, Chang A (2006) Quality control of a mutant plasma membrane ATPase: ubiquitylation prevents cell-surface stability. Journal of Cell Science 119: 360-369 doi: 10.1242/jcs.02749

Liu Y, Oppenheim RW, Sugiura Y, Lin W (2009) Abnormal development of the neuromuscular junction in Nedd4-deficient mice. Dev Biol 330: 153-166 doi: 10.1016/j.ydbio.2009.03.023

Lu D, Lin W, Gao X, Wu S, Cheng C, Avila J, Heese A, Devarenne TP, He P, Shan L (2011) Direct ubiquitination of pattern recognition receptor FLS2 attenuates plant innate immunity. Science 332: 1439-1442 doi: 10.1126/science. 1204903

Lu D, Wu S, Gao X, Zhang Y, Shan L, He P (2010) A receptor-like cytoplasmic kinase, BIK1, associates with a flagellin receptor complex to initiate plant innate immunity. Proc Natl Acad Sci U S A 107: 496-501 doi: 10.1073/pnas.0909705107

Lu PJ, Zhou XZ, Shen M, Lu KP (1999) Function of WW domains as phosphoserine- or phosphothreonine-binding modules. Science 283: 1325-1328 doi:

Luhtala N, Odorizzi G (2004) Bro1 coordinates deubiquitination in the multivesicular body pathway by recruiting Doa4 to endosomes. J Cell Biol 166: 717-729 doi: 10.1083/jcb.200403139

Löfke C, Luschnig C, Kleine-Vehn J (2013) Posttranslational modification and trafficking of PIN auxin efflux carriers. Mech Dev 130: 82-94 doi: 10.1016/j.mod.2012.02.003

MacGurn JA, Hsu P-C, Emr SD (2012) Ubiquitin and Membrane Protein Turnover: From Cradle to Grave. Annual Review of Biochemistry, Vol 81 81: 231-259 doi: 10.1146/annurev-biochem060210-093619

MacGurn JA, Hsu PC, Smolka MB, Emr SD (2011) TORC1 regulates endocytosis via Npr1-mediated phosphoinhibition of a ubiquitin ligase adaptor. Cell 147: 1104-1117 doi: 10.1016/j.cell.2011.09.054

Mayran N, Parton RG, Gruenberg J (2003) Annexin II regulates multivesicular endosome biogenesis in the degradation pathway of animal cells. EMBO J 22: 3242-3253 doi: 10.1093/emboj/cdg321 
Meckel T, Hurst AC, Thiel G, Homann U (2004) Endocytosis against high turgor: intact guard cells of Vicia faba constitutively endocytose fluorescently labelled plasma membrane and GFP-tagged K-channel KAT1. Plant J 39: 182-193 doi: 10.1111/j.1365-313X.2004.02119.x

Merhi A, André B (2012) Internal amino acids promote Gap1 permease ubiquitylation via TORC1/Npr1/14-3-3-dependent control of the Bul arrestin-like adaptors. Mol Cell Biol 32: 4510-4522 doi: 10.1128/MCB.00463-12

Metzger MB, Hristova VA, Weissman AM (2012) HECT and RING finger families of E3 ubiquitin ligases at a glance. J Cell Sci 125: 531-537 doi: 10.1242/jcs.091777

Miao Y, Zentgraf U (2010) A HECT E3 ubiquitin ligase negatively regulates Arabidopsis leaf senescence through degradation of the transcription factor WRKY53. Plant $\mathrm{J}$ 63: 179-188 doi: 10.1111/j.1365-313X.2010.04233.x

Michelle C, Vourc'h P, Mignon L, Andres CR (2009) What was the set of ubiquitin and ubiquitin-like conjugating enzymes in the eukaryote common ancestor? J Mol Evol 68: 616-628 doi: 10.1007/s00239-009-9225-6

Mochida GH, Ganesh VS, de Michelena MI, Dias H, Atabay KD, Kathrein KL, Huang HT, Hill RS, Felie JM, Rakiec D, Gleason D, Hill AD, Malik AN, Barry BJ, Partlow JN, Tan WH, Glader LJ, Barkovich AJ, Dobyns WB, Zon LI, Walsh CA (2012) CHMP1A encodes an essential regulator of BMI1-INK4A in cerebellar development. Nat Genet 44: 1260-1264 doi: 10.1038/ng.2425

Morita E, Sandrin V, McCullough J, Katsuyama A, Baci Hamilton I, Sundquist WI (2011) ESCRT-III protein requirements for HIV-1 budding. Cell Host Microbe 9: 235-242 doi: 10.1016/j.chom.2011.02.004

Morrione A, Plant P, Valentinis B, Staub O, Kumar S, Rotin D, Baserga R (1999) mGrb10 interacts with Nedd4. J Biol Chem 274: 24094-24099 doi:

Mulet JM, Martin DE, Loewith R, Hall MN (2006) Mutual antagonism of target of rapamycin and calcineurin signaling. J Biol Chem 281: 33000-33007 doi: 10.1074/jbc.M604244200

Murdaca J, Treins C, Monthouël-Kartmann MN, Pontier-Bres R, Kumar S, Van Obberghen E, GiorgettiPeraldi S (2004) Grb10 prevents Nedd4-mediated vascular endothelial growth factor receptor-2 degradation. J Biol Chem 279: 26754-26761 doi: 10.1074/jbc.M311802200

Muzioł T, Pineda-Molina E, Ravelli RB, Zamborlini A, Usami Y, Göttlinger H, Weissenhorn W (2006) Structural basis for budding by the ESCRT-III factor CHMP3. Dev Cell 10: 821-830 doi: 10.1016/j.devcel.2006.03.013

Mäser P, Thomine S, Schroeder JI, Ward JM, Hirschi K, Sze H, Talke IN, Amtmann A, Maathuis FJ, Sanders D, Harper JF, Tchieu J, Gribskov M, Persans MW, Salt DE, Kim SA, Guerinot ML (2001) Phylogenetic relationships within cation transporter families of Arabidopsis. Plant Physiol 126: 1646-1667 doi:

Nabhan JF, Pan H, Lu Q (2010) Arrestin domain-containing protein 3 recruits the NEDD4 E3 ligase to mediate ubiquitination of the beta2-adrenergic receptor. EMBO Rep 11: 605-611 doi: 10.1038/embor.2010.80

Naik N, Giannini E, Brouchon L, Boulay F (1997) Internalization and recycling of the C5a anaphylatoxin receptor: evidence that the agonist-mediated internalization is modulated by phosphorylation of the C-terminal domain. J Cell Sci 110 ( Pt 19): 2381-2390 doi:

Nakamura N, Tanaka S, Teko Y, Mitsui K, Kanazawa H (2005) Four Na+/H+ exchanger isoforms are distributed to Golgi and post-Golgi compartments and are involved in organelle $\mathrm{pH}$ regulation. $\mathrm{J}$ Biol Chem 280: 1561-1572 doi: 10.1074/jbc.M410041200

Nass R, Cunningham KW, Rao R (1997) Intracellular sequestration of sodium by a novel $\mathrm{Na}+\mathrm{H}+$ exchanger in yeast is enhanced by mutations in the plasma membrane H+-ATPase. Insights into mechanisms of sodium tolerance. J Biol Chem 272: 26145-26152 doi:

Nass R, Rao R (1998) Novel localization of a Na+/H+ exchanger in a late endosomal compartment of yeast. Implications for vacuole biogenesis. J Biol Chem 273: 21054-21060 doi:

Navarrete C, Petrezselyova S, Barreto L, Martinez JL, Zahradka J, Arino J, Sychrova H, Ramos J (2010) Lack of main K plus uptake systems in Saccharomyces cerevisiae cells affects yeast performance in both potassium-sufficient and potassium-limiting conditions. Fems Yeast Research 10: 508517 doi: $10.1111 / \mathrm{j} .1567-1364.2010 .00630 . x$

Needham PG, Brodsky JL (2013) How early studies on secreted and membrane protein quality control gave rise to the ER associated degradation (ERAD) pathway: The early history of ERAD. Biochim Biophys Acta 10.1016/j.bbamcr.2013.03.018

Nickerson DP, West M, Odorizzi G (2006) Did2 coordinates Vps4-mediated dissociation of ESCRT-III from endosomes. J Cell Biol 175: 715-720 doi: 10.1083/jcb.200606113 
Nijman SM, Luna-Vargas MP, Velds A, Brummelkamp TR, Dirac AM, Sixma TK, Bernards R (2005) A genomic and functional inventory of deubiquitinating enzymes. Cell 123: 773-786 doi: 10.1016/j.cell.2005.11.007

Nikko E, Pelham HR (2009) Arrestin-mediated endocytosis of yeast plasma membrane transporters. Traffic 10: 1856-1867 doi: 10.1111/j.1600-0854.2009.00990.x

Nikko E, Sullivan JA, Pelham HR (2008) Arrestin-like proteins mediate ubiquitination and endocytosis of the yeast metal transporter Smf1. EMBO Rep 9: 1216-1221 doi: 10.1038/embor.2008.199

Núñez-Ramírez R, Sánchez-Barrena MJ, Villalta I, Vega JF, Pardo JM, Quintero FJ, Martinez-Salazar J, Albert A (2012) Structural insights on the plant salt-overly-sensitive 1 (SOS1) $\mathrm{Na}(+) / \mathrm{H}(+)$ antiporter. J Mol Biol 424: 283-294 doi: 10.1016/j.jmb.2012.09.015

O'Neill LA (2011) Plant science. Innate immunity in plants goes to the PUB. Science 332: 1386-1387 doi: $10.1126 /$ science. 1208448

Obita T, Saksena S, Ghazi-Tabatabai S, Gill DJ, Perisic O, Emr SD, Williams RL (2007) Structural basis for selective recognition of ESCRT-III by the AAA ATPase Vps4. Nature 449: 735-739 doi: 10.1038/nature06171

Oliver PM, Cao X, Worthen GS, Shi P, Briones N, MacLeod M, White J, Kirby P, Kappler J, Marrack P, Yang B (2006) Ndfip1 protein promotes the function of itch ubiquitin ligase to prevent $\mathrm{T}$ cell activation and $\mathrm{T}$ helper 2 cell-mediated inflammation. Immunity 25: 929-940 doi: 10.1016/j.immuni.2006.10.012

Ostrowski M, Carmo NB, Krumeich S, Fanget I, Raposo G, Savina A, Moita CF, Schauer K, Hume AN, Freitas RP, Goud B, Benaroch P, Hacohen N, Fukuda M, Desnos C, Seabra MC, Darchen F, Amigorena S, Moita LF, Thery C (2010) Rab27a and Rab27b control different steps of the exosome secretion pathway. Nat Cell Biol 12: 19-30; sup pp 11-13 doi: 10.1038/ncb2000

Otegui MS, Spitzer C (2008) Endosomal functions in plants. Traffic 9: 1589-1598 doi: 10.1111/j.16000854.2008.00787.x

Pals-Rylaarsdam R, Hosey MM (1997) Two homologous phosphorylation domains differentially contribute to desensitization and internalization of the $\mathrm{m} 2$ muscarinic acetylcholine receptor. $\mathrm{J}$ Biol Chem 272: 14152-14158 doi:

Parikh H, Carlsson E, Chutkow WA, Johansson LE, Storgaard H, Poulsen P, Saxena R, Ladd C, Schulze PC, Mazzini MJ, Jensen CB, Krook A, Björnholm M, Tornqvist H, Zierath JR, Ridderstråle M, Altshuler D, Lee RT, Vaag A, Groop LC, Mootha VK (2007) TXNIP regulates peripheral glucose metabolism in humans. PLoS Med 4: e158 doi: 10.1371/journal.pmed.0040158

Parkinson N, Ince PG, Smith MO, Highley R, Skibinski G, Andersen PM, Morrison KE, Pall HS, Hardiman O, Collinge J, Shaw PJ, Fisher EM, Study MPiA, Consortium F (2006) ALS phenotypes with mutations in CHMP2B (charged multivesicular body protein 2B). Neurology 67: 1074-1077 doi: 10.1212/01.wnl.0000231510.89311.8b

Patra B, Pattanaik S, Yuan L (2013) Ubiquitin protein ligase 3 mediates the proteasomal degradation of GLABROUS 3 and ENHANCER OF GLABROUS 3, regulators of trichome development and flavonoid biosynthesis in Arabidopsis. Plant J 74: 435-447 doi: 10.1111/tpj.12132

Patwari P, Chutkow WA, Cummings K, Verstraeten VL, Lammerding J, Schreiter ER, Lee RT (2009) Thioredoxin-independent regulation of metabolism by the alpha-arrestin proteins. J Biol Chem 284: 24996-25003 doi: 10.1074/jbc.M109.018093

Patwari P, Lee RT (2012) An expanded family of arrestins regulate metabolism. Trends Endocrinol Metab 23: 216-222 doi: 10.1016/j.tem.2012.03.003

Pawliczek T, Crump CM (2009) Herpes simplex virus type 1 production requires a functional ESCRT-III complex but is independent of TSG101 and ALIX expression. J Virol 83: 11254-11264 doi: 10.1128/JVI.00574-09

Peer WA (2011) Plasma Membrane Protein Trafficking. In: Murphy A, Peer W, Schultz B (eds) The Plant Plasma Membrane. Springer-Verlag, Berlin, Germany, pp. 31-56.

Perez-Valle J, Jenkins H, Merchan S, Montiel V, Ramos J, Sharma S, Serrano R, Yenush L (2007) Key role for intracellular $\mathrm{K}+$ and protein kinases Sat4/Hal4 and Ha15 in the plasma membrane stabilization of yeast nutrient transporters. Molecular and Cellular Biology 27: 5725-5736 doi: 10.1128/mcb.01375-06

Perez-Valle J, Rothe J, Primo C, Martinez Pastor M, Arino J, Pascual-Ahuir A, Miguel Mulet J, Serrano R, Yenush L (2010) Hal4 and Hal5 Protein Kinases Are Required for General Control of Carbon and Nitrogen Uptake and Metabolism. Eukaryotic Cell 9: 1881-1890 doi: 10.1128/ec.00184-10

Persaud A, Alberts P, Amsen EM, Xiong X, Wasmuth J, Saadon Z, Fladd C, Parkinson J, Rotin D (2009) Comparison of substrate specificity of the ubiquitin ligases Nedd4 and Nedd4-2 using proteome arrays. Mol Syst Biol 5: 333 doi: 10.1038/msb.2009.85 
Peruzzi F, Prisco M, Morrione A, Valentinis B, Baserga R (2001) Anti-apoptotic signaling of the insulinlike growth factor-I receptor through mitochondrial translocation of c-Raf and Nedd4. J Biol Chem 276: 25990-25996 doi: 10.1074/jbc.M103188200

Philips JA, Porto MC, Wang H, Rubin EJ, Perrimon N (2008) ESCRT factors restrict mycobacterial growth. Proc Natl Acad Sci U S A 105: 3070-3075 doi: 10.1073/pnas.0707206105

Pickart CM (2004) Back to the future with ubiquitin. Cell 116: 181-190 doi:

Pizzirusso M, Chang A (2004) Ubiquitin-mediated targeting of a mutant plasma membrane ATPase, Pma1-7, to the endosomal/vacuolar system in yeast. Molecular Biology of the Cell 15: 24012409 doi: 10.1091/mbc.E03-10-0727

Poteryaev D, Datta S, Ackema K, Zerial M, Spang A (2010) Identification of the switch in early-to-late endosome transition. Cell 141: 497-508 doi: 10.1016/j.cell.2010.03.011

Prag G, Watson H, Kim YC, Beach BM, Ghirlando R, Hummer G, Bonifacino JS, Hurley JH (2007) The Vps27/Hse1 complex is a GAT domain-based scaffold for ubiquitin-dependent sorting. Dev Cell 12: 973-986 doi: 10.1016/j.devcel.2007.04.013

Qiu QS, Fratti RA (2010) The Na+/H+ exchanger Nhx1p regulates the initiation of Saccharomyces cerevisiae vacuole fusion. J Cell Sci 123: 3266-3275 doi: 10.1242/jcs.067637

Quintero FJ, Martinez-Atienza J, Villalta I, Jiang X, Kim WY, Ali Z, Fujii H, Mendoza I, Yun DJ, Zhu JK, Pardo JM (2011) Activation of the plasma membrane Na/H antiporter Salt-Overly-Sensitive 1 (SOS1) by phosphorylation of an auto-inhibitory C-terminal domain. Proc Natl Acad Sci U S A 108: 2611-2616 doi: 10.1073/pnas.1018921108

Raymond CK, Howald-Stevenson I, Vater CA, Stevens TH (1992) Morphological classification of the yeast vacuolar protein sorting mutants: evidence for a prevacuolar compartment in class E vps mutants. Mol Biol Cell 3: 1389-1402 doi:

Reid E, Connell J, Edwards TL, Duley S, Brown SE, Sanderson CM (2005) The hereditary spastic paraplegia protein spastin interacts with the ESCRT-III complex-associated endosomal protein CHMP1B. Hum Mol Genet 14: 19-38 doi: 10.1093/hmg/ddi003

Reyes FC, Buono R, Otegui MS (2011) Plant endosomal trafficking pathways. Curr Opin Plant Biol 14: 666-673 doi: 10.1016/j.pbi.2011.07.009

Robatzek S, Chinchilla D, Boller T (2006) Ligand-induced endocytosis of the pattern recognition receptor FLS2 in Arabidopsis. Genes Dev 20: 537-542 doi: 10.1101/gad.366506

Roberg KJ, Rowley N, Kaiser CA (1997) Physiological regulation of membrane protein sorting late in the secretory pathway of Saccharomyces cerevisiae. J Cell Biol 137: 1469-1482 doi:

Rodriguez MS, Gwizdek C, Haguenauer-Tsapis R, Dargemont C (2003) The HECT ubiquitin ligase Rsp5p is required for proper nuclear export of mRNA in Saccharomyces cerevisiae. Traffic 4: 566-575 doi:

Rodríguez-Rosales MP, Gálvez FJ, Huertas R, Aranda MN, Baghour M, Cagnac O, Venema K (2009) Plant NHX cation/proton antiporters. Plant Signal Behav 4: 265-276 doi:

Rolim AL, Lindsey SC, Kunii IS, Fujikawa AM, Soares FA, Chiamolera MI, Maciel RM, Silva MR (2010) Ion channelopathies in endocrinology: recent genetic findings and pathophysiological insights. Arq Bras Endocrinol Metabol 54: 673-681 doi:

Ronzaud C, Loffing-Cueni D, Hausel P, Debonneville A, Malsure SR, Fowler-Jaeger N, Boase NA, Perrier R, Maillard M, Yang B, Stokes JB, Koesters R, Kumar S, Hummler E, Loffing J, Staub O (2013) Renal tubular NEDD4-2 deficiency causes NCC-mediated salt-dependent hypertension. J Clin Invest 123: 657-665 doi: 10.1172/JCI61110

Rosati B, McKinnon D (2004) Regulation of ion channel expression. Circ Res 94: 874-883 doi: 10.1161/01.RES.0000124921.81025.1F

Rotin D, Kumar S (2009) Physiological functions of the HECT family of ubiquitin ligases. Nature Reviews Molecular Cell Biology 10: 398-409 doi: 10.1038/nrm2690

Rotin D, Staub O, Haguenauer-Tsapis R (2000) Ubiquitination and endocytosis of plasma membrane proteins: role of Nedd4/Rsp5p family of ubiquitin-protein ligases. J Membr Biol 176: 1-17 doi:

Rougier JS, van Bemmelen MX, Bruce MC, Jespersen T, Gavillet B, Apothéloz F, Cordonier S, Staub O, Rotin D, Abriel H (2005) Molecular determinants of voltage-gated sodium channel regulation by the Nedd4/Nedd4-like proteins. Am J Physiol Cell Physiol 288: C692-701 doi: 10.1152/ajpcell.00460.2004

Rue SM, Mattei S, Saksena S, Emr SD (2008) Novel Ist1-Did2 complex functions at a late step in multivesicular body sorting. Mol Biol Cell 19: 475-484 doi: 10.1091/mbc.E07-07-0694

Saksena S, Wahlman J, Teis D, Johnson AE, Emr SD (2009) Functional reconstitution of ESCRT-III assembly and disassembly. Cell 136: 97-109 doi: 10.1016/j.cell.2008.11.013

Samson RY, Obita T, Freund SM, Williams RL, Bell SD (2008) A role for the ESCRT system in cell division in archaea. Science 322: 1710-1713 doi: 10.1126/science.1165322 
Sasaki T, Takagi H (2013) Phosphorylation of a conserved Thr357 in yeast Nedd4-like ubiquitin ligase Rsp5 is involved in down-regulation of the general amino acid permease Gap1. Genes Cells $10.1111 /$ gtc. 12049

Schachtman DP, Schroeder JI, Lucas WJ, Anderson JA, Gaber RF (1992) Expression of an inwardrectifying potassium channel by the Arabidopsis KAT1 cDNA. Science 258: 1654-1658 doi:

Scheffner M, Huibregtse JM, Vierstra RD, Howley PM (1993) The HPV-16 E6 and E6-AP complex functions as a ubiquitin-protein ligase in the ubiquitination of p53. Cell 75: 495-505 doi:

Schellmann S, Pimpl P (2009) Coats of endosomal protein sorting: retromer and ESCRT. Curr Opin Plant Biol 12: 670-676 doi: 10.1016/j.pbi.2009.09.005

Schuetz F, Kumar S, Poronnik P, Adams DJ (2008) Regulation of the voltage-gated K(+) channels KCNQ2/3 and KCNQ3/5 by serum- and glucocorticoid-regulated kinase-1. Am J Physiol Cell Physiol 295: C73-80 doi: 10.1152/ajpcell.00146.2008

Schulman BA, Harper JW (2009) Ubiquitin-like protein activation by E1 enzymes: the apex for downstream signalling pathways. Nat Rev Mol Cell Biol 10: 319-331 doi: 10.1038/nrm2673

Schwarzer S, Kolacna L, Lichtenberg-Fraté H, Sychrova H, Ludwig J (2008) Functional expression of the voltage-gated neuronal mammalian potassium channel rat ether à go-go1 in yeast. FEMS Yeast Res 8: 405-413 doi: 10.1111/j.1567-1364.2007.00351.x

Sentenac H, Bonneaud N, Minet M, Lacroute F, Salmon JM, Gaymard F, Grignon C (1992) Cloning and expression in yeast of a plant potassium ion transport system. Science 256: 663-665 doi:

Shcherbik N, Kee Y, Lyon N, Huibregtse JM, Haines DS (2004) A single PXY motif located within the carboxyl terminus of Spt23p and Mga2p mediates a physical and functional interaction with ubiquitin ligase Rsp5p. J Biol Chem 279: 53892-53898 doi: 10.1074/jbc.M410325200

Shcherbik N, Zoladek T, Nickels JT, Haines DS (2003) Rsp5p is required for ER bound Mga2p120 polyubiquitination and release of the processed/tethered transactivator Mga2p90. Curr Biol 13: 1227-1233 doi:

Shea FF, Rowell JL, Li Y, Chang TH, Alvarez CE (2012) Mammalian alpha arrestins link activated seven transmembrane receptors to Nedd4 family e3 ubiquitin ligases and interact with beta arrestins. PLoS One 7: e50557 doi: 10.1371/journal.pone.0050557

Shearwin-Whyatt L, Dalton HE, Foot N, Kumar S (2006) Regulation of functional diversity within the Nedd4 family by accessory and adaptor proteins. Bioessays 28: 617-628 doi: 10.1002/bies.20422

Shen B, Li C, Min Z, Meeley RB, Tarczynski MC, Olsen OA (2003) sal1 determines the number of aleurone cell layers in maize endosperm and encodes a class $\mathrm{E}$ vacuolar sorting protein. Proc Natl Acad Sci U S A 100: 6552-6557 doi: 10.1073/pnas.0732023100

Shi PP, Cao XR, Sweezer EM, Kinney TS, Williams NR, Husted RF, Nair R, Weiss RM, Williamson RA, Sigmund CD, Snyder PM, Staub O, Stokes JB, Yang B (2008) Salt-sensitive hypertension and cardiac hypertrophy in mice deficient in the ubiquitin ligase Nedd4-2. Am J Physiol Renal Physiol 295: F462-470 doi: 10.1152/ajprenal.90300.2008

Shiels A, Bennett TM, Knopf HL, Yamada K, Yoshiura K, Niikawa N, Shim S, Hanson PI (2007) CHMP4B, a novel gene for autosomal dominant cataracts linked to chromosome 20q. Am J Hum Genet 81: 596-606 doi: 10.1086/519980

Shimkets RA, Warnock DG, Bositis CM, Nelson-Williams C, Hansson JH, Schambelan M, Gill JR, Ulick S, Milora RV, Findling JW (1994) Liddle's syndrome: heritable human hypertension caused by mutations in the beta subunit of the epithelial sodium channel. Cell 79: 407-414 doi:

Silvestri LS, Ruthel G, Kallstrom G, Warfield KL, Swenson DL, Nelle T, Iversen PL, Bavari S, Aman MJ (2007) Involvement of vacuolar protein sorting pathway in Ebola virus release independent of TSG101 interaction. J Infect Dis 196 Suppl 2: S264-270 doi: 10.1086/520610

Skibinski G, Parkinson NJ, Brown JM, Chakrabarti L, Lloyd SL, Hummerich H, Nielsen JE, Hodges JR, Spillantini MG, Thusgaard T, Brandner S, Brun A, Rossor MN, Gade A, Johannsen P, Sørensen SA, Gydesen S, Fisher EM, Collinge J (2005) Mutations in the endosomal ESCRTIII-complex subunit CHMP2B in frontotemporal dementia. Nat Genet 37: 806-808 doi: 10.1038/ng1609

Smith MH, Ploegh HL, Weissman JS (2011) Road to ruin: targeting proteins for degradation in the endoplasmic reticulum. Science 334: 1086-1090 doi: 10.1126/science.1209235

Snyder PM, Olson DR, Thomas BC (2002) Serum and glucocorticoid-regulated kinase modulates Nedd42-mediated inhibition of the epithelial Na+ channel. J Biol Chem 277: 5-8 doi: 10.1074/jbc.C100623200

Snyder PM, Steines JC, Olson DR (2004) Relative contribution of Nedd4 and Nedd4-2 to ENaC regulation in epithelia determined by RNA interference. J Biol Chem 279: 5042-5046 doi: 10.1074/jbc.M312477200 
Spitzer C, Reyes FC, Buono R, Sliwinski MK, Haas TJ, Otegui MS (2009) The ESCRT-related CHMP1A and $\mathrm{B}$ proteins mediate multivesicular body sorting of auxin carriers in Arabidopsis and are required for plant development. Plant Cell 21: 749-766 doi: 10.1105/tpc.108.064865

Spitzer C, Schellmann S, Sabovljevic A, Shahriari M, Keshavaiah C, Bechtold N, Herzog M, Müller S, Hanisch FG, Hülskamp M (2006) The Arabidopsis elch mutant reveals functions of an ESCRT component in cytokinesis. Development 133: 4679-4689 doi: 10.1242/dev.02654

Staub O, Dho S, Henry P, Correa J, Ishikawa T, McGlade J, Rotin D (1996) WW domains of Nedd4 bind to the proline-rich PY motifs in the epithelial Na+ channel deleted in Liddle's syndrome. EMBO J 15: 2371-2380 doi:

Stauffer DR, Howard TL, Nyun T, Hollenberg SM (2001) CHMP1 is a novel nuclear matrix protein affecting chromatin structure and cell-cycle progression. J Cell Sci 114: 2383-2393 doi:

Sullivan JA, Lewis MJ, Nikko E, Pelham HR (2007) Multiple interactions drive adaptor-mediated recruitment of the ubiquitin ligase rsp5 to membrane proteins in vivo and in vitro. Mol Biol Cell 18: 2429-2440 doi: 10.1091/mbc.E07-01-0011

Sutter JU, Sieben C, Hartel A, Eisenach C, Thiel G, Blatt MR (2007) Abscisic acid triggers the endocytosis of the arabidopsis KAT1 K+ channel and its recycling to the plasma membrane. Curr Biol 17: 1396-1402 doi: 10.1016/j.cub.2007.07.020

Szaszi K, Paulsen A, Szabo EZ, Numata M, Grinstein S, Orlowski J (2002) Clathrin-mediated endocytosis and recycling of the neuron-specific $\mathrm{Na}+\mathrm{H}+$ exchanger NHE5 isoform. Regulation by phosphatidylinositol 3'-kinase and the actin cytoskeleton. J Biol Chem 277: 42623-42632 doi: 10.1074/jbc.M206629200

Takahashi H, Nozawa A, Seki M, Shinozaki K, Endo Y, Sawasaki T (2009) A simple and high-sensitivity method for analysis of ubiquitination and polyubiquitination based on wheat cell-free protein synthesis. BMC Plant Biol 9: 39 doi: 10.1186/1471-2229-9-39

Takano J, Miwa K, Yuan L, von Wirén N, Fujiwara T (2005) Endocytosis and degradation of BOR1, a boron transporter of Arabidopsis thaliana, regulated by boron availability. Proc Natl Acad Sci U S A 102: 12276-12281 doi: 10.1073/pnas.0502060102

Takano J, Tanaka M, Toyoda A, Miwa K, Kasai K, Fuji K, Onouchi H, Naito S, Fujiwara T (2010) Polar localization and degradation of Arabidopsis boron transporters through distinct trafficking pathways. Proc Natl Acad Sci U S A 107: 5220-5225 doi: 10.1073/pnas.0910744107

Tang W, Ruknudin A, Yang WP, Shaw SY, Knickerbocker A, Kurtz S (1995) Functional expression of a vertebrate inwardly rectifying $\mathrm{K}+$ channel in yeast. Mol Biol Cell 6: 1231-1240 doi:

Teis D, Saksena S, Emr SD (2008) Ordered assembly of the ESCRT-III complex on endosomes is required to sequester cargo during MVB formation. Dev Cell 15: 578-589 doi: 10.1016/j.devcel.2008.08.013

Tian M, Xie Q (2013) Non-26S proteasome proteolytic role of ubiquitin in plant endocytosis and endosomal trafficking(F). J Integr Plant Biol 55: 54-63 doi: 10.1111/jipb.12007

Tian Q, Olsen L, Sun B, Lid SE, Brown RC, Lemmon BE, Fosnes K, Gruis DF, Opsahl-Sorteberg HG, Otegui MS, Olsen OA (2007) Subcellular localization and functional domain studies of DEFECTIVE KERNEL1 in maize and Arabidopsis suggest a model for aleurone cell fate specification involving CRINKLY4 and SUPERNUMERARY ALEURONE LAYER1. Plant Cell 19: 3127-3145 doi: 10.1105/tpc.106.048868

Toyoshima M, Tanaka N, Aoki J, Tanaka Y, Murata K, Kyuuma M, Kobayashi H, Ishii N, Yaegashi N, Sugamura K (2007) Inhibition of tumor growth and metastasis by depletion of vesicular sorting protein Hrs: its regulatory role on E-cadherin and beta-catenin. Cancer Res 67: 5162-5171 doi: 10.1158/0008-5472.CAN-06-2756

Trajkovic K, Dhaunchak AS, Goncalves JT, Wenzel D, Schneider A, Bunt G, Nave KA, Simons M (2006) Neuron to glia signaling triggers myelin membrane exocytosis from endosomal storage sites. J Cell Biol 172: 937-948 doi: 10.1083/jcb.200509022

Tu C, Ahmad G, Mohapatra B, Bhattacharyya S, Ortega-Cava CF, Chung BM, Wagner KU, Raja SM, Naramura M, Band V, Band H (2011) ESCRT proteins: Double-edged regulators of cellular signaling. Bioarchitecture 1: 45-48 doi: 10.4161/bioa.1.1.15173

Usami Y, Popov S, Popova E, Göttlinger HG (2008) Efficient and specific rescue of human immunodeficiency virus type 1 budding defects by a Nedd4-like ubiquitin ligase. J Virol 82: 4898-4907 doi: 10.1128/JVI.02675-07

Usami Y, Popov S, Popova E, Inoue M, Weissenhorn W, G Göttlinger H (2009) The ESCRT pathway and HIV-1 budding. Biochem Soc Trans 37: 181-184 doi: 10.1042/BST0370181

Vallier LG, Carlson M (1991) New SNF genes, GAL11 and GRR1 affect SUC2 expression in Saccharomyces cerevisiae. Genetics 129: 675-684 doi: 
Van Belle D, André B (2001) A genomic view of yeast membrane transporters. Curr Opin Cell Biol 13: 389-398 doi:

van Bemmelen MX, Rougier JS, Gavillet B, Apothéloz F, Daidié D, Tateyama M, Rivolta I, Thomas MA, Kass RS, Staub O, Abriel H (2004) Cardiac voltage-gated sodium channel Nav1.5 is regulated by Nedd4-2 mediated ubiquitination. Circ Res 95: 284-291 doi: 10.1161/01.RES.0000136816.05109.89

Vecchione A, Marchese A, Henry P, Rotin D, Morrione A (2003) The Grb10/Nedd4 complex regulates ligand-induced ubiquitination and stability of the insulin-like growth factor I receptor. Mol Cell Biol 23: 3363-3372 doi:

Viotti C, Bubeck J, Stierhof YD, Krebs M, Langhans M, van den Berg W, van Dongen W, Richter S, Geldner N, Takano J, Jürgens G, de Vries SC, Robinson DG, Schumacher K (2010) Endocytic and secretory traffic in Arabidopsis merge in the trans-Golgi network/early endosome, an independent and highly dynamic organelle. Plant Cell 22: 1344-1357 doi: 10.1105/tpc.109.072637

Waguri S, Dewitte F, Le Borgne R, Rouillé Y, Uchiyama Y, Dubremetz JF, Hoflack B (2003) Visualization of TGN to endosome trafficking through fluorescently labeled MPR and AP-1 in living cells. Mol Biol Cell 14: 142-155 doi: 10.1091/mbc.E02-06-0338

Wang J, Ding Y, Hillmer S, Miao Y, Lo SW, Wang X, Robinson DG, Jiang L (2010) EXPO, an exocystpositive organelle distinct from multivesicular endosomes and autophagosomes, mediates cytosol to cell wall exocytosis in Arabidopsis and tobacco cells. Plant Cell 22: 4009-4030 doi: 10.1105/tpc.110.080697

Wang X, Trotman LC, Koppie T, Alimonti A, Chen Z, Gao Z, Wang J, Erdjument-Bromage H, Tempst P, Cordon-Cardo C, Pandolfi PP, Jiang X (2007) NEDD4-1 is a proto-oncogenic ubiquitin ligase for PTEN. Cell 128: 129-139 doi: 10.1016/j.cell.2006.11.039

Webster G, Berul CI (2013) An update on channelopathies: from mechanisms to management. Circulation 127: 126-140 doi: 10.1161/CIRCULATIONAHA.111.060343

Winter V, Hauser MT (2006) Exploring the ESCRTing machinery in eukaryotes. Trends Plant Sci 11: 115-123 doi: 10.1016/j.tplants.2006.01.008

Wittinger M, Vanhara P, El-Gazzar A, Savarese-Brenner B, Pils D, Anees M, Grunt TW, Sibilia M, Holcmann M, Horvat R, Schemper M, Zeillinger R, Schöfer C, Dolznig H, Horak P, Krainer M (2011) hVps37A Status affects prognosis and cetuximab sensitivity in ovarian cancer. Clin Cancer Res 17: 7816-7827 doi: 10.1158/1078-0432.CCR-11-0408

Wolfe DM, Pearce DA (2006) Channeling studies in yeast: yeast as a model for channelopathies? Neuromolecular Med 8: 279-306 doi: 10.1385/NMM:8:3:279

Wollert T, Wunder C, Lippincott-Schwartz J, Hurley JH (2009) Membrane scission by the ESCRT-III complex. Nature 458: 172-177 doi: 10.1038/nature07836

Woodman P (2009) ESCRT proteins, endosome organization and mitogenic receptor down-regulation. Biochem Soc Trans 37: 146-150 doi: 10.1042/BST0370146

Wright MH, Berlin I, Nash PD (2011) Regulation of endocytic sorting by ESCRT-DUB-mediated deubiquitination. Cell Biochem Biophys 60: 39-46 doi: 10.1007/s12013-011-9181-9

Wu N, Zheng B, Shaywitz A, Dagon Y, Tower C, Bellinger G, Shen CH, Wen J, Asara J, McGraw TE, Kahn BB, Cantley LC (2013) AMPK-dependent degradation of TXNIP upon energy stress leads to enhanced glucose uptake via GLUT1. Mol Cell 49: 1167-1175 doi: 10.1016/j.molcel.2013.01.035

Xinhan L, Matsushita M, Numaza M, Taguchi A, Mitsui K, Kanazawa H (2011) Na+/H+ exchanger isoform 6 (NHE6/SLC9A6) is involved in clathrin-dependent endocytosis of transferrin. Am J Physiol Cell Physiol 301: C1431-1444 doi: 10.1152/ajpcell.00154.2011

Yamaguchi T, Fukada-Tanaka S, Inagaki Y, Saito N, Yonekura-Sakakibara K, Tanaka Y, Kusumi T, Iida $\mathrm{S}$ (2001) Genes encoding the vacuolar $\mathrm{Na}+\mathrm{H}+$ exchanger and flower coloration. Plant Cell Physiol 42: 451-461 doi:

Yang B, Gay DL, MacLeod MK, Cao X, Hala T, Sweezer EM, Kappler J, Marrack P, Oliver PM (2008) Nedd4 augments the adaptive immune response by promoting ubiquitin-mediated degradation of Cbl-b in activated T cells. Nat Immunol 9: 1356-1363 doi: 10.1038/ni.1670

Yang B, Kumar S (2010) Nedd4 and Nedd4-2: closely related ubiquitin-protein ligases with distinct physiological functions. Cell Death and Differentiation 17: 68-77 doi: 10.1038/cdd.2009.84

Yang KS, Jin UH, Kim J, Song K, Kim SJ, Hwang I, Lim YP, Pai HS (2004) Molecular characterization of NbCHMP1 encoding a homolog of human CHMP1 in Nicotiana benthamiana. Mol Cells 17: 255-261 doi:

Ye Y, Rape M (2009) Building ubiquitin chains: E2 enzymes at work. Nat Rev Mol Cell Biol 10: 755764 doi: $10.1038 / \mathrm{nrm} 2780$ 
Yoshida K, Kawachi M, Mori M, Maeshima M, Kondo M, Nishimura M, Kondo T (2005) The involvement of tonoplast proton pumps and $\mathrm{Na}+(\mathrm{K}+) / \mathrm{H}+$ exchangers in the change of petal color during flower opening of Morning Glory, Ipomoea tricolor cv. Heavenly Blue. Plant Cell Physiol 46: 407-415 doi: 10.1093/pcp/pci057

Zaks-Makhina E, Kim Y, Aizenman E, Levitan ES (2004) Novel neuroprotective K+ channel inhibitor identified by high-throughput screening in yeast. Mol Pharmacol 65: 214-219 doi: 10.1124/mol.65.1.214

Zhang J, Li W, Xiang T, Liu Z, Laluk K, Ding X, Zou Y, Gao M, Zhang X, Chen S, Mengiste T, Zhang Y, Zhou JM (2010) Receptor-like cytoplasmic kinases integrate signaling from multiple plant immune receptors and are targeted by a Pseudomonas syringae effector. Cell Host Microbe 7 : 290-301 doi: 10.1016/j.chom.2010.03.007

Zhang L, Anglesio MS, O'Sullivan M, Zhang F, Yang G, Sarao R, Mai PN, Cronin S, Hara H, Melnyk N, Li L, Wada T, Liu PP, Farrar J, Arceci RJ, Sorensen PH, Penninger JM (2007) The E3 ligase HACE1 is a critical chromosome 6q21 tumor suppressor involved in multiple cancers. Nat Med 13: 1060-1069 doi: 10.1038/nm1621

Zhang XQ, Hou P, Zhu HT, Li GD, Liu XG, Xie XM (2013) Knockout of the VPS22 component of the ESCRT-II complex in rice (Oryza sativa L.) causes chalky endosperm and early seedling lethality. Mol Biol Rep 40: 3475-3481 doi: 10.1007/s11033-012-2422-1

Zhou R, Kabra R, Olson DR, Piper RC, Snyder PM (2010) Hrs controls sorting of the epithelial Na+ channel between endosomal degradation and recycling pathways. J Biol Chem 285: 3052330530 doi: 10.1074/jbc.M110.150755

Zoladek T, Tobiasz A, Vaduva G, Boguta M, Martin NC, Hopper AK (1997) MDP1, a Saccharomyces cerevisiae gene involved in mitochondrial/cytoplasmic protein distribution, is identical to the ubiquitin-protein ligase gene RSP5. Genetics 145: 595-603 doi: 

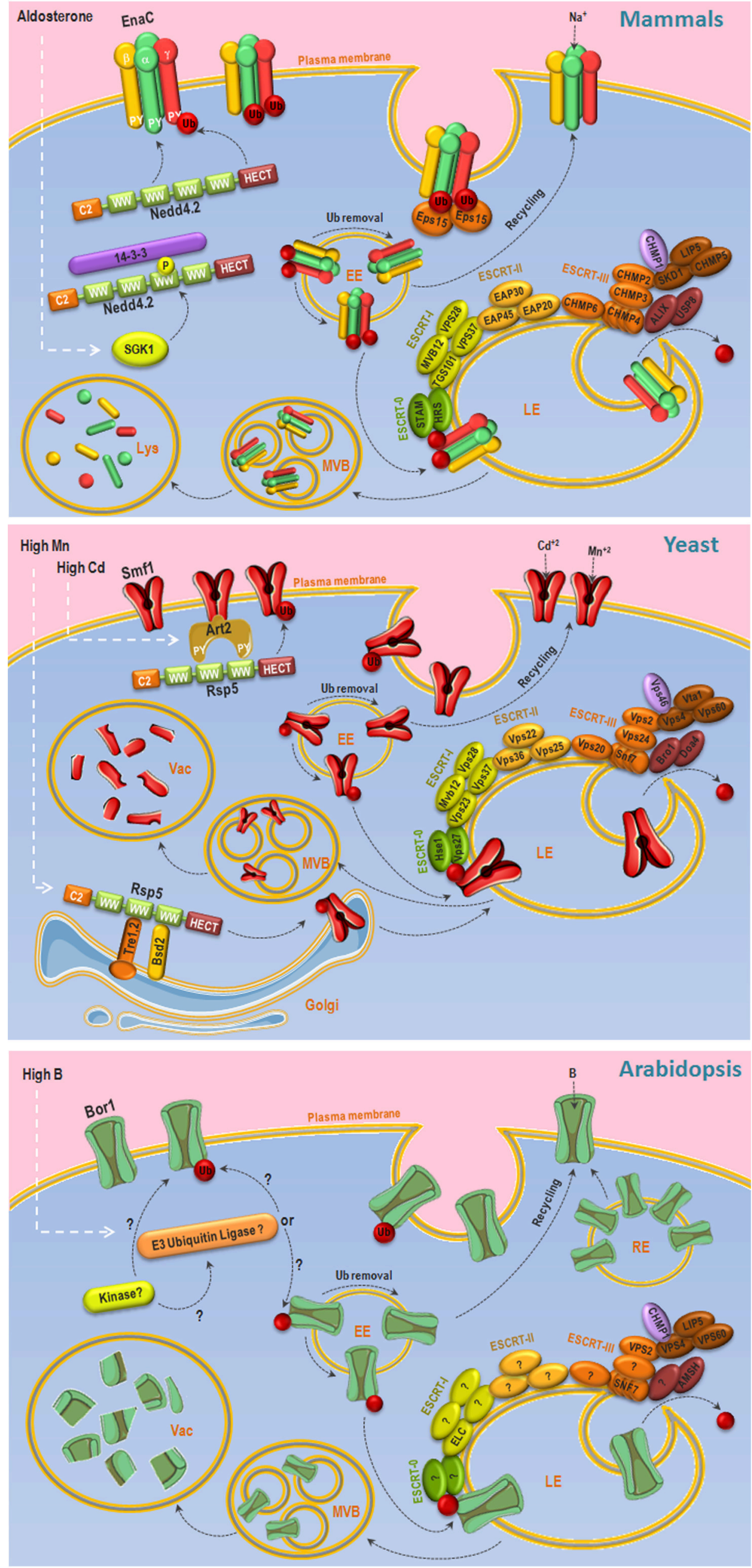

Fig. 1 


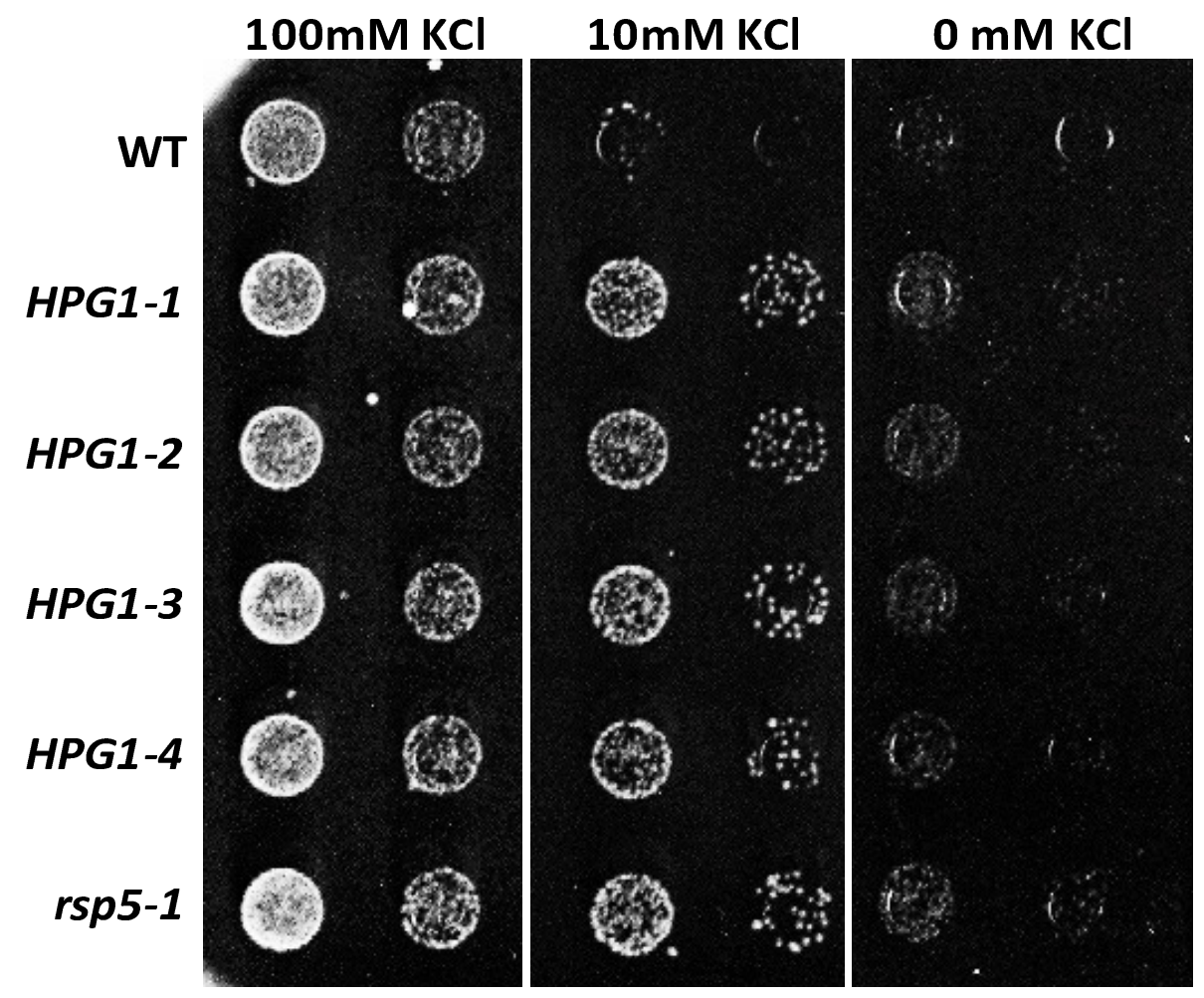

Fig. 2 